\title{
PRINCÍPIOS dE CATEGORIZAÇÃO NAS \\ LINGUAGENS DOCUMENTÁRIAS
}

\begin{abstract}
Dissertação apresentada à Escola de Comunicações e Artes da Universidade de São Paulo, como exigência parcial para a obtenção do título de Mestre. Programa de Pós-Graduação em Ciência da Informação.

Área de concentração: Cultura e Informação

Linha de Pesquisa: Acesso à Informação

Orientadora: Profa Dra Marilda Lopes Ginez de Lara
\end{abstract}




\section{Luciane Maria Artêncio}

Princípios de categorização nas linguagens documentárias.

Dissertação apresentada à Escola de Comunicações e Artes da Universidade de São Paulo, como exigência parcial para obtenção do título de Mestre. Programa de Pós-Graduação em Ciência da Informação.

Área de concentração: Cultura e Informação

Linha de Pesquisa: Acesso à Informação

Orientadora: Profa Dra Marilda Lopes Ginez de Lara

Aprovado em:

Presidente da Banca:

Banca examinadora:

Prof.Dr.: Instituição:

Prof.Dr.: Instituição:

Prof.Dr.: Instituição: 
Ao Luiz Antônio, companheiro de todas as horas e em todas as circunstâncias;

\section{À Bianca, Giulia $e$ Giorgio,}

pela motivação e compreensão nas minhas ausências;

Ao Antônio, meu pai (in memorian),

À Zaira, minha mãe,

Ao Carlos, Maria Augusta, Renata e Antônio, meus irmãos, pelo carinho e apoio incondicional. 
Á Profa Dra Marilda Lopes Ginez de Lara, minha orientadora, que acreditou em meu potencial, abriu-me a porta e me incentivou incansavelmente.

À Profa Dra Maria de Fátima G. Tálamo e à Profa Dra Johanna Smit, pelas sugestões antes e durante o exame de qualificação.

A todos os meus amigos do Instituto de Fomento e Coordenação Industrial - IFI / CTA, especialmente à Direção e Vice-Direção, pelo apoio e confiança que depositaram em mim e nos resultados desse trabalho.

Às colegas da Biblioteca do Instituto Tecnológico de Aeronáutica - ITA / CTA, pela atenção dispensada nas minhas buscas bibliográficas.

Um trabalho não se realiza na solidão.

Ele é fruto da comunhão de esforços, incentivos, perseverança e, acima de tudo, da amizade e do carinho daqueles que nos rodeiam. 
"A ambivalência, possibilidade de conferir a um objeto ou evento mais de uma categoria, é uma desordem específica da linguagem, uma falha da função nomeadora (segregadora) que a linguagem deve desempenhar. O principal sintoma de desordem é o agudo desconforto que sentimos quando somos incapazes de ler adequadamente a situação $e$ optar entre ações alternativas. (...) A ambivalência é [no entanto], o alter ego da linguagem, sua companheira permanente - com efeito, sua condição normal.” 
ARTÊNCIO, L.M. Princípios de categorização nas linguagens documentárias. São Paulo, 2007. Dissertação (Mestrado em Ciência da Informação) - Escola de Comunicação e Artes, Universidade de São Paulo.

Para verificar como a noção de categoria é utilizada historicamente nas linguagens documentárias, partimos de uma breve sistematização das propostas de categorização na filosofia, tal como ela se apresenta em Aristóteles, Kant e Wittgenstein, na semântica cognitiva, segundo Lakoff, com base em Rosch, e na sociologia do conhecimento, com Mauss. Analisamos, em seguida, reflexões feitas sobre a categorização nas linguagens documentárias realizadas por autores clássicos da Biblioteconomia - Shera, Dahlberg, Piedade, Fonseca, Grolier - e pelos autores contemporâneos - Blair e Iyer. O levantamento permitiu verificar que as noções de categoria e de categorização, embora nem sempre trabalhadas de modo explícito na literatura da Biblioteconomia e Ciência da Informação, permeiam os princípios de elaboração das linguagens documentárias refletindo, de certo modo, as várias formas de conceber os conceitos. Os sistemas enciclopédicos de classificação tendem a utilizar o conceito a partir de Aristóteles, aplicando-o prioritariamente como noção de classe que se divide, de modo apriorístico e sucessivo, em gêneros e espécies etc., procedimento que se altera gradativamente por influência de Kant, quando a noção passa a privilegiar as propriedades dos objetos e fenômenos. Atualmente existe uma tendência fugaz de categorização nas linguagens documentárias de acordo com as variações socioculturais, enfatizando as funções e locais onde estas variações ocorrem. Este procedimento confere maior flexibilidade à linguagem documentária.

Descritores: Categorização, Categorias, Organização do conhecimento, Categorização filosófica, Categorização semântico-cognitiva, Categorização sócio-cultural, Teoria da Classificação, Linguagens documentárias. 
ARTÊNCIO, L.M. Categorization's principles in documentary language. São Paulo, 2007. Dissertação (Master in Information Science) - Escola de Comunicação e Artes, Universidade de São Paulo.

In order to find out how the concept of category is historically used in documentary language we start from a limited systematization of philosophy categorization as proposed by Aristotle, Kant and Wittgenstein, the cognitive semantic categorization according to Lakoff who based his proposal on Rosch, and in knowledge sociology as per Mauss. We then proceed to analyze categorization of documentary language as presented by Librarianship classic authors such as Shera, Dahlberg, Piedade, Fonseca, and Groiler. We also looked into the contemporary authors Blair and Iyer. The investigation allowed us to see that although not always apparent in the literature of Librarianship and Information Science, the notion of category and categorization is implicit in the principles of documentary language elaboration which influences the several ways of elaborating concepts. The encyclopedic classification systems have a tendency of utilizing concepts according to Aristotle, applying it as a notion of class which breaks down according to priority, successiveness, genre, type, etc. This classification style was gradually altered by Kant, where the concept of category and categorization first emphasizes the properties of objects and phenomena. Today we see a brief tendency to categorizing documentary language according to social and cultural variations, observing the functions and sites where the processes occur. This tendency allows more flexibility to documentary language.

Descriptors: Categorization, Categories, Knowledge organization, Philosophical categorization, Cognitive and semantic categorization, Social and cultural categorization, Classification theory, Documentary languages. 


\section{LISTA DE FIGURAS}

Figura 1 - Modelo de semelhança de família de Wittgenstein

Figura 2 - Estrutura interna de uma categoria segundo a teoria dos

protótipos

Figura 3 - Triângulo conceitual de Dahlberg

109

Figura 4 - Estrutura graduada de três categorias 
2 A categorização como forma de conhecimento segundo as

várias teorias

2.1 A categorização no contexto filosófico 21

2.1.1 A noção de categoria em Aristóteles 24

2.1.2 As categorias em Kant 28

2.1.3 A visão do II Wittgenstein 34

2.2 A categorização sob a perspectiva da semântica cognitiva 41

2.3 Uma proposta da sociologia do conhecimento 48

3 Como a categorização se manifesta nas linguagens

documentárias

3.1 $\mathrm{O}$ entendimento de categoria na Biblioteconomia e na $\mathrm{Cl}$

54

3.2 A visão de autores clássicos da Biblioteconomia sobre a

3.2.1 Sistematizações de Shera, Vickery, Dahlberg e Fonseca

3.2.2 O relatório de Grolier sobre as categorias 72

3.3 A categorização aplicada na $\mathrm{Cl}$ sob a ótica das investigações

filosóficas

3.3.1 A contribuição da filosofia da linguagem

90

3.3.2 A categorização em Blair 97

3.3.3 A categorização em lyer

107

4 Considerações finais 
A revolução das tecnologias da informação desencadeou, nas Instituições de coleta, tratamento e transferência da informação (Bibliotecas, Centros de Informação e Documentação), uma nova realidade junto com a explosão documental. Essa nova realidade passou a exigir a revisão das relações entre as novas tecnologias e os processos de armazenamento, busca e recuperação da informação na vida daqueles que produzem, processam e consomem informação.

Como afirmou Citelli (2000), trata-se de uma corrida à integração no composto produção, circulação e recepção da informação procurando adequar as ferramentas de busca aos fluxos crítico-dialógicos dos discursos. Essa nova era tecnológica resultou um caos informacional, introduzindo sucessivamente novos meios de produção, de suportes e formas de transferência de informação alterando todo o processo de gestão, ora invertendo, ora eliminando algum dos papéis de agentes da informação (autores, editores, produtores, profissionais da informação, consumidores), ora excluindo, modificando ou criando novo procedimento de acesso, numa viagem permeada de obstáculos em busca da 
informação desejada até consolidar-se como conhecimento (BARRETO, 1999).

A assimilação das novas tecnologias pela Ciência da Informação ainda não chegou a dispensar os procedimentos anteriores de organização da informação para o acesso. Ao contrário, tem reafirmado a necessidade do tratamento prévio da informação, tamanha é a massa informacional que integra cotidianamente a web, como os acervos de bibliotecas e demais sistemas de informação.

Esse processo, ora intensificado, solicita o uso de procedimentos específicos de análise e síntese da informação, onde a linguagem exerce papel fundamental. De fato, já na década de 70, percebeu-se que a linguagem poderia apresentar-se como ferramenta de trabalho para o conhecimento sistematizado (TÁLAMO, 1997), surgindo daí a Linguagem Documentária (LD) que atua com a finalidade de representar e comunicar a informação especializada operando como ponte entre a linguagem natural (usuário) e as linguagens de especialidades (especialistas).

A partir da abordagem que vê a questão da comunicação documentária como essencialmente um problema de linguagem, muitos esforços foram empreendidos pelos profissionais da informação para criar mecanismos que pudessem facilitar a circulação da informação institucionalizada. Tal empreendimento tem estimulado os estudos na área da CI voltados à questão da linguagem, envolvendo disciplinas tais como a lógica, a filosofia, a terminologia e a lingüística. 
O resultado desses trabalhos é fundamental para enfrentar as novas situações de busca de informação, uma vez que a comunicação em ambientes documentários, anteriormente marcada pela presença do profissional da informação sempre disponível a auxiliar o usuário em suas necessidades de informação foi, e tem sido, profundamente alterada. $\mathrm{Na}$ atualidade, a realidade é de um mundo mediado pela Internet, bancos de dados, busca e recuperação da informação a distância, o que exige cada vez mais a eficácia dos instrumentos de organização para o acesso.

Do ponto de vista do reconhecimento da natureza lingüística da atividade documentária, buscou-se aprimorar as metodologias para aproximar a linguagem de entrada ou de acesso ao sistema à linguagem de recuperação da informação. Esse empreendimento procurou controlar e reduzir as distorções, minimizando os índices de ruído e silêncio nos procedimentos de prospecção da informação (GARCÍA GUTIÉRREZ; LUCAS FERNANDÉZ, 1987).

O problema da comunicação em ambientes documentários e informacionais ficou em evidência, principalmente a partir das reflexões sobre a LD iniciadas na década de 70 (TÁLAMO, 1997). No bojo dessas discussões encontra-se a questão da estruturação das LDs, cuja base são os princípios de categorização utilizados. São as categorias um dos principais vínculos de aderência dos usuários aos sistemas informacionais.

Verifica-se, concretamente, que os tesauros, modalidade contemporânea de LD, usam temas para reunir os assuntos a partir de uma espécie de 
organização consensual ${ }^{1}$ ou senso comum. Ocorre que a simplificação do problema através de acordo puramente consensual para a reunião dos assuntos como meio de organizar a informação de domínios de especialidade, não trouxe resultados positivos à questão, já que, nesse caso, não há embasamento teórico para respaldar e garantir a consistência das referências de categorização.

Para a CI, a categorização é um processo essencial para a organização do conhecimento, da informação e de sua representação. As categorias são conceitos de alta generalização que, no pensamento tradicional, são identificadas como "classes que resultam da divisão do universo de conhecimento, de acordo com as características intrínsecas ou fundamentais de cada conceito" (CAVALCANTI, 1978 citado por SMIT et.al., s.d.).

Observa-se, no entanto, que nas LD as categorias são agrupamentos pragmáticos que manifestam particularidades em relação às áreas do conhecimento ou de atividade não havendo normalmente a adequação aos princípios da verificabilidade. De fato, as categorias usadas na Documentação não são universais, mas servem a propósitos institucionais ou pontos de vista.

\footnotetext{
${ }^{1}$ Aqui nesse contexto, a organização consensual deve ser entendida como a utilização de determinada forma de organização da informação para distintos públicos com distintas necessidades informacionais, sem o cuidado da segmentação de público e de comunidades com as quais a Ciência da Informação deve trabalhar no planejamento de Sistemas de Informação.
} 
Os mais recentes estudos denotam que a categorização se reveste de aspectos sócio-cognitivos que as diferenças culturais lhe imprimem, um dos motivos que nos estimularam a investigar sobre o tema, levando-nos a observar os critérios utilizados para definir as categorias pelas correntes de pensamento contemporâneas mais significativas que trabalham a questão.

A discussão sobre categorização é bastante complexa, não existindo unanimidade quanto aos princípios para sua formulação. Considerando sua importância para a organização da informação, propomo-nos a verificar, neste trabalho, algumas das contribuições sobre o assunto visando identificar os princípios utilizados e os problemas de sua operacionalização. Pretendemos, principalmente, verificar como a literatura da CI vê a questão, analisando seus fundamentos e aplicação nas linguagens documentárias contemporâneas.

Compreender como a ciência é estruturada ao longo do tempo ajuda a entender os arranjos estabelecidos nos esquemas de organização e classificação, como também traçar estratégias visando aperfeiçoar os sistemas de acesso à informação.

Notadamente, as ocorrências passadas relativas às tentativas de ordenação do conhecimento confundem-se com a própria história da ciência. Esse fato comprova que a ciência caracteriza-se pela sua dinamicidade, o que foi anteriormente apontado por Lund e Taube (1937 citado por VICKERY, 1980, p.187). 
Avaliada no âmbito documentário, entende-se a categorização como um processo que possibilita a organização da informação que, na definição de Lara, "pressupõe arranjo, síntese, sistematização, agrupamento por critérios pré-determinados que são pontos de vista sobre a realidade" (LARA, s.d.). Tal definição implica em dizer que a categorização deve obedecer aos múltiplos perfis regionais, incluindo-se aí a etnia lingüística, os aspectos sócio-cognitivos e culturais, fatores determinantes para a estruturação da LD.

A rápida evolução das tecnociências observada no período pós-guerra é apontada como determinante na quebra de paradigmas dos métodos de recuperação da informação, com o desenvolvimento de sistemas utilizados, de modos mecânicos ou eletromagnéticos, posteriormente eletrônicos, para as transformações de estruturas de classificações ou das codificações documentárias (GROLIER, 1962). A atualização dessa informação impõe incluir as tecnologias digitais que, à sua base, devem considerar princípios de ordenação relacionados às diversidades das formas de ver a informação.

Ao lado das necessidades de trabalhar em rede, de instituir protocolos de comunicação, de padronizar procedimentos e ferramentas para agilizar a transferência da informação que provocaram reavaliações nas bases teóricas da representação e recuperação da informação, é necessário observar que ocorrem alterações nas formas de conceber a informação. Continua atual a observação de Vickery (1980, p.25) sobre a importância 
da organização da informação na recuperação da informação, já que de um lado, temos a literatura universal de Ciência e Tecnologia, passada e presente, em diversos idiomas e, do outro, um usuário com uma indagação, uma necessidade de informação. Entre um e outro lado pode haver um abismo que só será transposto se forem criadas condições para estabelecer uma adequada co-relação, que tem nas formas de categorização uma possibilidade de concretização.

Partindo da proposta de sistematização bibliográfica sobre os estudos relacionados à categorização nas linguagens documentárias, propomo-nos a avaliar as correntes que trabalham o tema, percorrendo a questão sob diferentes enfoques, sem, no entanto, pretender esgotar o assunto. 0 objetivo deste trabalho é, antes, o de levantar aspectos que nos parecem significativos para promover a discussão dos principais fundamentos contemporâneos ou não, sobre a categorização no domínio do processo documentário, aliando tais princípios às formas sociais de organização da informação.

Outrossim, a categorização é abordada por vários campos de conhecimento e teorias, destacando-se entre eles a Filosofia, a Psicologia, a Antropologia, a Lingüística, a Sociologia e, não obstante, a CI. É interessante notar que o processo de categorização é tão antigo quanto a própria Lógica, embora sua aplicação em classificação seja relativamente nova.

A partir dessa perspectiva, o trabalho foi organizado do seguinte modo: 
Após esta Introdução, o Capítulo 2 nos conduzirá a conhecer as primeiras propostas de investigação sobre as categorias do conhecimento registradas pela Filosofia, a partir da exposição das principais discussões sobre o tema. Parte desse capítulo será dedicado à teoria de Aristóteles (382-322a.C) que instituiu os princípios da Classificação como o "conjunto de características abstratas que são reunidas num todo individualizado, transformando essa soma individualizada na totalidade de características abstratas que torna a coisa real em questão" (SHERA, 1957). Deriva dessa doutrina a ciência da classificação aristotélica em gêneros, espécies e sub-espécies, que constitui a doutrina de Predicação e da Substância Primária, responsável pelos conceitos da conjunção de atributos e disjunção de substâncias primárias. O valor das estruturas classificatórias aristotélicas encontradas nas LDs e em outras ferramentas de informação é indiscutível. Ainda no mesmo capítulo, abordaremos a teoria kantiana que propõe uma ruptura com as escolas filosóficas anteriores, até o início do séc. XVIII, no que tange às categorias, o que leva Kant a ser reconhecido como o pai da filosofia moderna. Na seqüência, apresentaremos os aspectos mais significativos sobre a questão da categorização a partir da contribuição do II Wittgenstein.

Incluímos, também, neste segundo Capítulo, uma introdução à abordagem da Semântica Cognitiva, de Lakoff, que recorre à Eleanor Rosh para falar sobre a categorização, como também uma breve exposição sobre o tema na perspectiva de Mauss, um dos fundadores da Sociologia do Conhecimento. 
O Capítulo 3 será dedicado a analisar como a categorização se manifesta nas LDs, primeiramente, apresentando sistematizações de alguns autores clássicos da Biblioteconomia e Documentação. Julgamos importante realizar uma breve retrospectiva a respeito de como a área refletia sobre a questão da organização da informação e da categorização particularmente por meio da Teoria da Classificação. Na seqüência, incluímos duas abordagens mais recentes da Biblioteconomia e CI sobre o tema.

As considerações finais são reunidas no Capítulo 4, em que tentamos realizar um ensaio aproximativo sobre os impactos das reflexões sobre categoria e categorização, de outras disciplinas, na elaboração de Linguagens Documentárias no campo da Ciência da Informação. 


\section{A CATEGorizaÇÃo COMO FORMA dE CONHECIMENTO SEGUNDO AS VÁRIAS TEORIAS}

Em uma de suas primeiras viagens à China, Marco Polo depara-se com uma criatura extraordinária. Algo que Ihe desafia a memória, a qual vasculha em busca de uma definição. Afinal, que espécie de criatura seria aquela? Sabe que se trata de um animal, pois identifica nele quatro patas, um chifre em cima do nariz, assim como um unicórnio que na sua experiência pessoal seria uma criatura até então somente presente em fábulas e contos.

Desse modo, Marco Polo vai aos poucos tentando se apossar daquela nova entidade lançando mão dos recursos disponíveis em sua experiência, e sentencia: "É uma besta muito feia de se ver. Não é como se diz por aqui, que ela se deixe pegar como uma donzela, mas acontece o contrário" (Milione 143, citado por ECO, 1998, p.55-56). Enfim, desiste de classificar o animal que vê a partir dos dados de que dispõe e resolve simplesmente acrescentar o novo animal ao universo dos seres vivos, evitando, assim, cometer um engano. Não se sentia seguro o bastante para arriscar-se 
numa exploração taxionômica aprofundada que descrevesse um rinoceronte.

Assim pode ser compreendida a reação do homem diante do desconhecido, que vasculha em sua enciclopédia pessoal o 'recorte de conteúdo' (conforme expressão utilizada por Eco no texto acima referido) mais próximo que dê conta da nova entidade. Diante de uma criatura desconhecida, por analogia, vai criando associações a outras, iniciando o seu processo de apreensão, esforçando-se para organizar a sua experiência, como uma forma de dispor os atributos de algo numa determinada ordem e de estabelecer relações entre o já conhecido e o desconhecido, utilizando um procedimento de aproximação (ECO, 1998).

Embora a categorização seja uma função essencial nos processos de memória, linguagem, raciocínio e resolução de problemas, comumente não Ihe atribuímos a devida importância. Constantemente, no entanto, estamos identificando novos objetos, fenômenos, fatos, sentimentos e lidando com todas essas novidades cotidianas através da capacidade cognitiva que emprega a categorização em um de seus momentos.

A compreensão de como se desencadeia a ação cognitiva no ser humano é imprescindível na medida em que partimos daí para evidenciarmos a questão da representação, que compreende a categorização, tema deste trabalho. 
$\mathrm{Na}$ tentativa de verificar como a categorização pode ser abordada, faremos uma incursão nos campos da filosofia, da psicologia, da lingüística- semiótica.

\subsection{A CATEGORIZAÇÃo NO CONTEXTO FILOSÓFico}

A questão da categorização se rebate nas atividades de classificação e de categorização das informações e, baseadas ou não nas categorias filosóficas, sempre se remetem a ela. Eis que não é possível falar em categorização na área de CI sem nos reportarmos às origens do conceito de categoria na filosofia.

Nesse século tão marcado pelas necessidades vitais e práticas, a filosofia é considerada a chave para a compreensão do homem e do mundo. Diante das exigências e da mudança contínua das tecnologias da informação, observa-se a necessidade de reavaliar a relação entre o homem, o trabalho e a inteligência. O mundo contemporâneo tão caracterizado pela técnica torna-se objeto de reflexão da filosofia e nela inclui-se a necessidade de refletir sobre a atividade documentária e demais processos relacionados.

A filosofia foi definida de múltiplas maneiras por grandes filósofos: Platão definia a filosofia como um saber verdadeiro que deve ser usado em benefício dos seres humanos; Descartes dizia que a filosofia é o estudo da 
sabedoria, conhecimento perfeito de todas as coisas que os humanos podem alcançar para o uso da vida, a conservação da saúde e a invenção das técnicas e das artes; Kant afirmou que a filosofia é o conhecimento que a razão adquire de si mesma para saber o que pode conhecer e o que pode fazer, tendo como finalidade a felicidade humana; Merleau-Ponty afirmou que a filosofia é um despertar para ver e mudar nosso mundo; Espinosa declarou que a filosofia é um caminho árduo e difícil, mas que pode ser percorrido por todos, se desejarem a liberdade e a felicidade (CHAUÍ, 1995).

Numa abordagem mais pragmática e recente, Mario Vargas Llosa, em visita a um casal amigo em Bruxelas [2006], extraiu dessa oportunidade um modelo que aplica o pensamento filosófico para "tornar a vida mais compreensível e tolerável". Esse sábio casal fez Vargas Llosa compreender que:

(...) a cultura, a literatura, as artes, a filosofia, desanimalizam os seres humanos, ampliam extraordinariamente seu horizonte vital, atiçam sua curiosidade, sua sensibilidade, sua fantasia, seus apetites, seus sonhos, os tornam mais porosos às amizades e ao diálogo, e melhor preparados para enfrentar a infelicidade (VARGAS LLOSA, 2006, p.D8).

Foram mais além, intuindo que fazem do pensamento filosófico a sua razão de ser, porque acreditam que a filosofia "explica a vida e ajuda a viver" (LLOSA, 2006, p.D8). 
É exatamente na atividade filosófica que a discussão sobre categorias ocorre de modo privilegiado, o que justifica a incursão nesse campo do conhecimento. A necessidade de conhecer é inerente ao ser humano. As doutrinas filosóficas amparam as questões científicas, sugerindo ou fazendo compreender os modos de organizar e sistematizar o pensar.

Ainda que Platão tenha sido reconhecido como o primeiro filósofo a se manifestar sutilmente sobre a classificação do conhecimento, Aristóteles é apontado como aquele que se aprofundou sobre a questão das categorias para propor a primeira classificação geral do conhecimento ou das ciências. Para Aristóteles, a classificação geral do conhecimento contemplava "todos os saberes referentes a todos os seres, todas as ações e produções humanas distribuídas da ciência mais alta (a filosofia primeira) até a tecnologia para a fabricação de objetos" (CHAUÍ, 1995, p.183). Aristóteles elaborou os preceitos da Lógica que empregava princípios de categorização na busca por uma classificação que compreendesse todas as áreas do conhecimento.

No início do séc. XVIII, Immanuel Kant propôs um novo rumo aos ideais filosóficos consolidados até então, transformando-se desse modo, em um marco para a filosofia moderna.

Mais recentemente, Ludwig Wittgenstein em suas investigações filosóficas, introduz as "semelhanças de família" que ajudam a explicar os "jogos de linguagem", oferecendo uma nova abordagem sobre a linguagem e as observações que motivam a repensar o entendimento de categorias. 
Com o objetivo de aproximarmos as origens do conceito de categorização na filosofia às questões documentárias, registraremos, nas seções seguintes, alguns traços das doutrinas de Aristóteles, de Kant e de Wittgenstein que ajudam a compreender os diferentes modos de abordar a questão.

\subsubsection{A noção de categoria em Aristóteles}

Aristóteles nasceu em Estagira, na Calcídia, território macedônico, cujo idioma era o grego. Por esse motivo, Aristóteles ficou conhecido como Aristóteles de Estagira, ou, como o Estagirita. Filósofo grego, discípulo de Platão, professor do Príncipe da Macedônia, seu pensamento compreende várias áreas do conhecimento como Lógica, Ética, Política, Teologia, Metafísica, Poética, Retórica, Antropologia, Física e Biologia. Sua doutrina tem como traço marcante a tradição, pois pretendia não apenas rever como também, de acordo com a sua avaliação, corrigir as falhas e imperfeições das filosofias anteriores. No entanto, foi além e apresentou novos caminhos para fundamentar suas críticas, revisões e proposições. Como fundador da Lógica, Aristóteles não a considerava uma ciência teorética, nem prática ou produtiva, mas sim um instrumento para as ciências, o que explica por que o conjunto das obras lógicas aristotélicas recebeu o nome de Órganon, palavra grega que significa 'instrumento'. 
Chauí descreve as principais características da lógica aristotélica, de modo bastante didático:

- instrumental: é o instrumento do pensamento para pensar corretamente e verificar a correção do que está sendo pensado;

- formal: não se ocupa com os conteúdos pensados ou com os objetos referidos pelo pensamento, mas apenas com a forma pura e geral dos pensamentos, expressas através da linguagem ${ }^{2}$;

- propedêutica: é o que devemos conhecer antes de iniciar uma investigação científica ou filosófica, pois somente ela pode indicar os procedimentos (métodos, raciocínios, demonstrações) que devemos empregar para cada modalidade de conhecimento;

- normativa: fornece princípios, leis, regras e normas que todo pensamento deve seguir se quiser ser verdadeiro;

- doutrina da prova: estabelece as condições e os fundamentos necessários de todas as demonstrações. Dada uma hipótese, permite verificar as conseqüências necessárias que dela decorrem, dada uma conclusão, permite verificar se é verdadeira ou falsa;

- geral ou temporal: as formas do pensamento, seus princípios e suas leis não dependem do tempo e do lugar, nem das pessoas e circunstâncias, mas não são universais, necessárias e imutáveis como a própria razão (CHAUÍ, 1995, p.183).

$\mathrm{Na}$ doutrina aristotélica, coloca-se a proposição como objetivo da lógica, que utiliza a linguagem para expressar os juízos formulados pelo pensamento. Entende-se por proposição a atribuição de um predicado a um sujeito, na forma $S$ é $P$. A sucessão dos juízos resulta no raciocínio, que é expresso logicamente através da conexão de proposições, cuja idéia

2 "No século $X X$, os lógicos afirmavam que a lógica aristotélica não deveria ser considerada plenamente formal porque Aristóteles não afastara por inteiro os conteúdos pensados para ficar apenas com a forma vazia de conteúdo. No entanto, vamos aqui manter essa característica para a lógica aristotélica, porque, se comparada à dialética platônica, nela o papel do conteúdo pensado é menor do que a forma de pensamento, estudada pelo filósofo" (CHAUÍ, 1995, p.183.). 
é denominada 'silogismo'. Portanto, o objeto de estudo da lógica são os elementos que constituem uma proposição (as categorias).

Na doutrina de Aristóteles, termo ou categoria é "aquilo que serve para designar uma coisa", ou seja, palavras não combinadas com outras e que aparecem em tudo quanto pensamos e dizemos (CHAUÍ, 1995). Para o Estagirita, as categorias ou termos são empregados para indicar o que uma coisa é ou faz, expressando o que nossa percepção e nosso pensamento captam imediata e diretamente numa coisa.

O dicionário de Lalande traz a seguinte definição de categoria em Aristóteles: "(...) predicado da proposição; ou então categorias do ser $(\ldots)$, as diferentes classes de um ser ou as diferentes classes de predicados que se pode afirmar sobre um sujeito qualquer" (LALANDE, 1992, v.1, p.125).

Sobre a questão das categorias em Aristóteles, o dicionário de Ferrater Mora registra que:

(...) [Aristóteles] divide as expressões em expressões sem enlace - como 'homem', 'é vencedor' - e expressões com enlace - como 'o homem corre', 'o homem é vencedor'. As expressões sem enlace não afirmam nem negam nada por si mesmas, senão ligadas a outras expressões. Mas as expressões sem enlace ou termos últimos e não analisáveis se agrupam em categorias (FERRATER MORA, 1971, v.1, p.264) (Tradução livre da autora).

Segundo o dicionário de Ferrater Mora,

(...) as categorias não são para Aristóteles somente termos sem enlace posteriormente analisáveis, mas também 
diversos modos de falar do ser como substância, qualidade, quantidade, etc., o qual seria impossível se o ser não estivesse articulado de acordo com tais modos de predicação (FERRATER MORA, 1971, v.1, p.265) (Tradução livre da autora).

Pode-se inferir dessa definição que as categorias são grupos de termos de alta generalização, uma vez que ainda não se encontram "aplicadas".

Partindo desse princípio, o Estagirita idealizou as dez categorias:

1. Substância (por exemplo, homem, Sócrates, animal);

2. Quantidade (por exemplo, dois metros de comprimento);

3. Qualidade (por exemplo, branco, grego, agradável);

4. Relação (por exemplo, o dobro, a metade, maior do que);

5. Lugar (por exemplo, em casa, na rua, no alto);

6. Tempo (por exemplo, ontem, hoje, agora);

7. Posição (por exemplo, sentado, deitado, de pé);

8. Posse (por exemplo, armado, isto é, tendo armas);

9. Ação (por exemplo, corta, fere, derrama);

10.Paixão ou passividade (por exemplo, está cortado, está ferido) (CHAUÍ, 1995, p.184).

Embora as categorias de Aristóteles sejam conhecidas em número de dez, não se pode afirmar, segundo o registro de Ferrater Mora, que tal número tenha sido definitivo para o Estagirita que:

(...) não considerava a lista das (dez) categorias como fixada de uma vez para sempre e que, em princípio, podia descobrir-se que uma categoria era redutível a outra, mas alguns autores não admitem esta interpretação e supõem que as categorias são e devem ser precisamente as dez indicadas (FERRATER MORA, 1971, v.1, p.264) (Tradução livre da autora). 
A partir de então até a época moderna, a doutrina sobre as categorias seguiu o destino de sucessivas reelaborações metafísicas, alterações que dependiam do modo como encarar o ente e de como se concebia sua articulação de diferentes maneiras. De modo geral, a validez objetiva das categorias estimulou a escola escocesa ${ }^{3}$ a supor que elas são como as noções comuns dos estóicos, não estão submetidas a discussões, por serem consideradas "princípios racionais comuns".

Apesar dessas observações, não se pode discutir o fato de que, ainda hoje, referimo-nos a Aristóteles e reconhecemos, na sua obra, inúmeras contribuições.

\subsubsection{As categorias em Kant}

A ruptura com as escolas filosóficas identificadas até o início do séc. XVIII ocorreu somente com a doutrina kantiana que propôs uma "revolução

\footnotetext{
${ }^{3}$ La escuela filosófica escocesa, llamada también "filosofia del sentido comum", se inició com Thomas Reid em Aberdeen y tuvo su primera manifestación em lãs comunicaciones presenteadas por dicho filósofo em la "Aberdeen Philosophical Society" (fundada em 1758), a veces conocida com el nombre de "Wise Club". (...) Limitemo-nos a destacar lãs siguientes opiniones de la escuela: (1) Poner em duda el sentido común es absurdo; los propios escépticos lo presuponen, o tienen que presupornelo si no quieren desembocar em paradojas; (2) Puede errarse em questiones de ehcho, pero no em cuestiones de principio, justamente lãs que establece el sentido común; (3) El sentido común es uma facultad que percibe la verdad por medio de um "impulso instantâneo, instintivo e irresistible" (Beattie); (4) El sentido común equivale a la razón, siempre que ésta si entienda como algo más que la argumentación; (5) Las verdades evidentes proclamadas por el sentido común no pueden demostrarse, sino solo "mostrarse". Estas y otras opiniones llevaban a los filósofos Del sentido común a oponerse a corrientes escépticas, fenomenistas, idealistas (o lãs que luego han sido llamadas fenomenistas e idealistas): Io característico de la escuela de que tratamos, desde el puento de vista de los "ismos", es el realismo y también, en gran medida, el "espiritualismo" - aunque en pricnipio una filosofía del sentido común puede asimismo ser naturalista. (FERRATER MORA, 1971. p.546-547).
} 
copernicana em filosofia". A doutrina de Kant debruça-se no embate sobre os princípios racionais: seria a razão inata ou adquirida?

O inatismo tem como pressuposto que nascemos trazendo em nossa inteligência não só os princípios racionais, mas também algumas idéias verdadeiras, que, por conseguinte, são idéias inatas.

A posição contrária é defendida pelo empirismo, cuja proposta é a de que a razão com seus princípios, seus procedimentos e suas idéias, é adquirida por nós através da experiência. Em grego, experiência se diz empeiria - donde, 'empirismo', 'conhecimento empírico', isto é, conhecimento adquirido por meio da experiência.

A questão, debatida durante séculos, pode ser respondida tomando-se como base o pensamento de Platão (século IV a.C.), filósofo grego, e de Descartes (século XVII), filósofo francês, que se inclinaram com maior atenção a esses temas, tanto que as expressões 'inatismo platônico' e 'inatismo cartesiano' foram cunhadas com seus homônimos (CHAUÍ, 1995).

Kant responde aos problemas do inatismo e do empirismo formulando um paradigma novo no qual considera que 'o sujeito do conhecimento é a razão universal' e não uma subjetividade pessoal e psicológica.

No entendimento de Kant a razão aparece como uma estrutura vazia, uma forma pura sem conteúdos que é universal, a mesma para todos os seres humanos e em qualquer tempo e espaço. Para Kant, a razão como 
estrutura vazia é inata, existe a priori, vem antes da experiência e não depende dela. Na concepção kantiana a experiência fornece a matéria (os conteúdos) do conhecimento para a razão, e esta, por sua vez, fornece a forma (universal e necessária) do conhecimento. A matéria do conhecimento vem depois da experiência - a posteriori. Kant coloca o conhecimento racional como requisito para a existência da filosofia e da ciência, que ocorre com a síntese que a razão realiza a partir de uma forma universal inata e de um conteúdo particular oferecido pela experiência.

Segundo a doutrina kantiana, a razão é compreendida por três estruturas a priori: a estrutura ou forma da sensibilidade (estrutura ou forma da percepção sensível ou sensorial); a estrutura ou forma do entendimento (intelecto ou inteligência) e a estrutura ou forma da razão propriamente dita, quando esta não se relaciona nem com os conteúdos da sensibilidade, nem com os conteúdos do entendimento, mas apenas consigo mesma. Ou seja, em Kant, a razão não conhece coisa alguma separada da sensibilidade e do entendimento, sua função é a de regular e de controlá-los (sensibilidade e o entendimento). A sensibilidade nos permite ter percepções. Assim, não importa que cada um de nós veja cores de uma certa maneira, ouça sons de uma determinada maneira, mas sim o fato de possuirmos propriedades espaciais e temporais que nos permitam perceber lugares, posições, situações e de termos experiência do passado, do presente da simultaneidade ou da continuidade dos acontecimentos. É essa organização espaço-temporal dos objetos do 
conhecimento que é inata, universal e necessária. Nessa perspectiva, o entendimento organiza os conteúdos que lhe são enviados pela sensibilidade, ou seja, organiza as percepções. Aqui atua a experiência, sob a forma do espaço e do tempo, empregando a razão, através do entendimento que organiza esses conteúdos empíricos.

Essa organização é que permite a transformação das percepções em conhecimentos intelectuais ou em conceitos. Por isso é que, em Kant, o entendimento é apriorístico (antes da experiência e independente dela), já que os conteúdos empíricos são organizados por um conjunto de elementos, as chamadas categorias a priori, e é com elas que o sujeito do conhecimento formula os conceitos. Sob esse aspecto, Ferrater Mora observa que Kant formulou uma doutrina sistemática das categorias enquanto conceitos puros do entendimento "que se referem, a priori, aos objetos da intuição em geral como funções lógicas" (FERRATER MORA, 1971, p.266). Considera as categorias como "as leis primeiras e irredutíveis do conhecimento, as razões fundamentais que determinam a forma e que regem o movimento" (LALANDE, 1992, p.125).

Kant organizou os dados da experiência segundo a qualidade, a quantidade, a causalidade, a finalidade, a verdade, a falsidade, a universalidade, a particularidade, reconhecidas, hoje, como as categorias kantianas. Segundo Ferrater Mora,

(...) [Kant] estabelece uma tabela de categorias deduzida do único princípio comum da faculdade do juízo e, assim, chega a um sistema de categorias que compreende: as categorias da quantidade (unidade, pluralidade, totalidade); as da 
qualidade (realidade, negação, limitação); a da relação (substância e acidente; causalidade e dependência; comunidade ou reciprocidade entre agente e paciente); as de modalidade (possibilidade-impossibilidade; existêncianão-existência; necessidade-contingência). Essas são as categorias originárias, junto às quais cabe mencionar as derivadas, chamadas por Kant predicáveis do entendimento puro em oposição aos predicamentos. As categorias são constitutivas, isto é, constituem 'o objeto do conhecimento e permitem, portanto, um saber da Natureza e uma verificação da verdade como verdade transcendental. O problema das categorias como problema fundamental da crítica da razão conduz ao problema da verdade como questão fundamental da filosofia. A dedução transcendental das categorias é 'a explicação do modo como se referem a objetos conceitos a priori, e se distingue a dedução empírica, que indica a maneira como um conceito foi adquirido por meio da experiência e de sua reflexão' (FERRATER MORA, 1971, p.266-267) (Tradução livre da autora).

O dicionário de Lalande ressalta que:

Para Kant e na escola kantiana, as categorias são os conceitos fundamentais do entendimento puro, formas a priori de nosso conhecimento, representando todas as funções essenciais do pensamento discursivo. Elas se deduzem da natureza do julgamento, considerado nas suas diferentes formas e compreendem quatro grandes classes: Quantidade, Qualidade, Relação, Modalidade (LALANDE, 1992, p.125) (Tradução livre da autora).

Segundo Chauí, para Kant as categorias são as mesmas em toda época e em todo lugar, para todos os seres racionais (CHAUÍ, 1995). A doutrina kantiana afirma que a razão e o sujeito do conhecimento possuem as estruturas espaciais, temporais, quantitativas, qualitativas, causais, etc. que permitem o conhecer e que, por elas serem universais e necessárias, o conhecimento é racional e verdadeiro para os seres humanos. É só a partir dessas estruturas que as ciências são possíveis e válidas. 
A perspectiva kantiana sobre a categorização pode ser interpretada como uma advertência à lógica aristotélica, já que essa última constituiu até pouco tempo a espinha dorsal dos sistemas de classificação bibliográfica. Partindo do pressuposto que os sistemas cingiram-se, quase sempre, a um tipo de relacionamento entre conceitos, fica claro que a relação mais acentuada na lógica aristotélica é a de inclusão (gênero-espécie), único tipo de relacionamento sob o qual foram elaborados os sistemas tradicionais de classificação bibliográfica, que gerou sistemas rigorosamente enumerativos.

Sobre essa questão, Dahlberg considera que, para os problemas de organização da informação da CI, é essencial considerar que

todo reconhecimento da realidade é de natureza hipotética, e há um mundo que é independente de nossa consciência, estruturado e que possui vida própria. Esse mundo é parcialmente reconhecido e compreendido pela percepção, pensamento e ciência intersubjetiva (...) A resposta a questão como é possível coincidir estruturas cognitivas e estruturas reais (pelo menos parcialmente) é dada pelo desenvolvimento do cosmos e do próprio homem como parte do cosmos (DAHLBERG, 1978, p.28) (Tradução livre da autora).

Esse argumento permite a Dahlberg assumir superar a abordagem da existência idealística que estabelece que a formação do conhecimento sobre o mundo acontece por meio das formas perceptivas a priori contida na doutrina kantiana (DAHLBERG, 1978, p.28). 


\subsubsection{A visão do II Wittgenstein}

Ludwig Wittgenstein (1889-1951) é reconhecido como um dos maiores e, talvez, o mais controverso filósofo contemporâneo. Discípulo de Gortlob Frege e de Bertrand Russell, Wittgenstein contribuiu para a renovação da Lógica na década de 20 , sendo aclamado como o pai da filosofia analítica.

Convencionalmente, a obra de Witttgenstein é referenciada a partir de seus dois trabalhos: Tractatus Logico-Philosophicus, publicado em 1921, fase que passou a ser conhecida como o 'I Wittgenstein'; e sua obra póstuma, Philosophical Investigations, datada de 1953, fase denominada 'II Wittgenstein', cujos resultados influenciaram muitos trabalhos posteriores em campos diversos à filosofia e aquela que nos interessa em especial nesse trabalho. Doravante, nesse trabalho, os dois períodos marcantes da obra de Wittgenstein - o I Wittgenstein e o II Wittgenstein serão assim referidos.

Pode-se afirmar que a filosofia é muito mais uma atividade puramente verbal do que uma ciência que reúne e colige fatos, como tantas outras. O filósofo dispõe de uma ferramenta peculiar, submetendo as suas idéias a testes por meio da discussão verbal. Esse o motivo pelo qual o filósofo é especialmente sensível às imperfeições de seu principal instrumento, decorrendo daí a importância que ele concede à linguagem. A partir desse fato compreende-se o motivo que levou Wittgenstein a estudar os problemas da filosofia da linguagem e do significado. 
Segundo Moreno (2000), o I Wittgenstein buscava responder o que é a linguagem e como ela opera; como pode ser capaz de dizer coisas; que fale do mundo; e, se seria possível pensar sem que a linguagem seja utilizada. Wittgenstein colocava essas indagações como centrais em sua obra, servindo-lhe como norte em seu primeiro trabalho. Para o I Wittgenstein, no qual imperava a teoria racionalista, a questão da significação era imaginada sob a existência de estabilidade entre a proposição e o fato representado.

Para melhor compreensão do pensamento de Wittgenstein, é preciso entender a proposição, já que ela adquire um valor fundamental em sua obra, pois é a partir dela que decorre todo o seu discurso teórico. O próprio filósofo escreveu, no início de 1915: "Toda minha tarefa consiste em explicar a essência da proposição" (WITTGENSTEIN citado por MARQUES, s.d.). Essa era uma atribuição a qual Wittgenstein havia se comprometido cumprir quando se dedicou a escrever o Tratactus, trabalho no qual pretendia circunscrever o limite de tudo o que pode ser expresso na linguagem e, assim, encontrar um entendimento crítico do propósito final da atividade filosófica.

A proposição é considerada como o objeto da lógica, que exprime, através da linguagem, os juízos formulados pelo pensamento. A proposição é a atribuição de um predicado a um sujeito, e constitui-se por elementos que são seus termos - ou categorias (CHAUÍ, 1995). Em outras palavras, a 
proposição pode ser compreendida como o enunciado de um juízo ou a sua expressão verbal. O juízo é formado por idéias ou conceitos.

Como um estudioso também da matemática pura, Wittgenstein se interessava em conhecer e até estabelecer uma forma lógica ou forma de representação para os fatos. Nesse sentido, o I Wittgenstein aborda a linguagem como uma variedade de articulações lógicas possíveis.

O Tractatus, avisa Wittgenstein, serve como pano de fundo para sua nova abordagem, personificada por sua obra póstuma "Investigações Filosóficas". Considerada por muitos pesquisadores como uma revisão do Tractatus, Wittgenstein não abandona os velhos critérios na elaboração das "Investigações Filosóficas", pois parte deles para um processo de elaboração e de aprofundamento das mesmas questões essenciais. Essa sua nova fase, o II Wittgenstein, se opõe à tradicional maneira de pensar a linguagem, na qual a proposição era tratada como uma forma definida da realidade.

A obra de Wittgenstein é comumente caracterizada por sua natureza filosoficamente anti-sistemática, especialmente em sua segunda fase, tanto na forma como no conteúdo. Há indícios de que ele adotou esse estilo por opção e chegava a compará-lo a um álbum contendo diversas fotos dos mesmos objetos em diferentes épocas e ângulos.

Afirma Wittgenstein em seu novo enfoque que "a proposição deixa de ser um modelo exato da realidade para ser uma hipótese", ou, "uma forma 
mais ou menos adequada de representação" (MORENO, 2000, p.55). A questão da significação, a partir do II Wittgenstein, é trabalhada a partir do pressuposto de que a estabilidade antes imaginada entre a proposição e o fato representado não mais existe, sobretudo, priorizando as circunstâncias nas quais a proposição é utilizada, em situações específicas de comunicação ou de expressão. Essa foi a concepção adotada pelo II Wittgenstein para a significação, deixando para trás a noção da "garantia da perfeita superposição do mundo, da linguagem e do pensamento, forma considerada lógica e a qual tornava possível pensarmos o mundo real e falarmos sobre ele" (Ibid., idem).

Diante desse novo enfoque, Wittgenstein introduz a noção de "jogos de linguagem", que coloca como foco a importância da praxis da linguagem. A linguagem, segundo Wittgenstein, é um tipo de jogo, um conjunto de "peças" ou "equipamentos" (palavras) que são usadas de acordo com um conjunto de regras (convenções lingüísticas). Nessa perspectiva, a linguagem passa a ser considerada como um caleidoscópio de situações de uso das palavras em que o contexto pragmático não pode mais ser eliminado (MORENO, 2000). Seria algo como mudar o traje adequando-o a cada ocasião social.

O abandono da compreensão do significado como determinação lógica e definitiva das unidades mínimas formais, sintáticas ou semânticas leva Wittgenstein a adotar outros fundamentos, que serão desde então, fornecidos pelo uso que fazemos da linguagem nos mais diversos jogos, 
ou, nas diferentes "formas de vida". Sob essa ótica em que a estabilidade do significado não mais existe, perdendo-se no "turbilhão" de diversas "formas de vida" as quais o homem exerce, uma tal "animalidade", a idéia de "formas de vida" é compreendida pela multiplicidade de atividades nas quais se insere a linguagem, tais como andar, comer, beber e jogar (MORENO, 2000).

Pode-se afirmar que no II Wittgenstein, a questão da experiência da significação é sempre imprecisa, bem como a sua representação. E é com essa imprecisão recheada de metáforas que Wittgenstein utilizou para esclarecer a noção de "semelhança de família".

Wittgenstein afirmava que a "semelhança de família" poderia ser empregada para caracterizar a linguagem sob sua nova concepção. Designando a linguagem sob uma metáfora, Wittgenstein se mantinha fiel às suas crenças e ao cuidado para não incorrer no risco de delimitar fronteiras precisas no significado das palavras, preocupação constante no II Wittgenstein. Utilizando uma expressão metafórica em lugar da linguagem, denominando-a "jogos de linguagem", Wittgenstein quis tão somente evitar as origens "das contusões que o entendimento recebeu ao correr de encontro às fronteiras da linguagem" (WITTGENSTEIN citado por MORENO, 2000, p.62). Podemos inferir que essa estratégia adotada pelo filósofo explica-se pelo fato de que os conceitos são delineados somente a partir de seu uso no discurso, não apresentando uma definição única e por isso mesmo, tampouco estável. 
Desse modo, a adoção de metáforas pelo filósofo cria um impasse no que se refere à questão da significação, pois sem estabelecer uma referência para um dado termo, sem identificar semelhanças, nem diferenças, como falar do mundo? A resposta surge do próprio Wittgenstein, afirma Moreno, e resulta de suas "Investigações filosóficas":

É possível traçar limites segundo objetivos determinados; mas isso não implica que tais limites existam por si próprios, independentemente dos objetivos que nós próprios traçamos - ou, dito de outra maneira, os limites dos conceitos não são independentes de nossa ação, ganhando consistência e sentido apenas na medida em que são relativos aos usos determinados que pretendemos fazer dos conceitos. A exatidão conceitual é, assim, um atributo do uso (MORENO, 2000, p.63-64).

Para explicar a aplicação das metáforas empregadas por Wittgenstein, Moreno (2000) toma como exemplo a expressão "jogos de linguagem", na qual a palavra "jogo" procura assimilar uma diversidade de elementos que contém vários outros tipos de atividades extralingüísticas. O significado de "jogo" não pode ser expresso por uma única propriedade característica que seja comum a todas as situações de jogos, capaz de definir seu sentido exato. A semelhança de família ampara a compreensão que reside na palavra "jogo" porque, numa analogia ao significado da linguagem, a propriedade de semelhança de família é o traço comum que permite identificar pessoas como pertencentes a uma mesma família. Assim, as características físicas de um membro de uma família $X$ podem ser diferentes as de seu pai. No entanto, esse membro pode ter traço(s) semelhante(s) ao de seu avô, e assim sucessivamente, compondo 
semelhanças que caracterizem a família, sem que essas características sejam necessariamente idênticas ou estáveis. A semelhança de família ocorre de forma descontinuada, aparecendo aqui e ali em gerações alternadas, sobretudo, permitindo a identificação de traços ao longo da cadeia de seus membros. Contudo, a propriedade que caracteriza determinada classe ou cadeia não é uma propriedade transitiva, isto é, não percorre necessariamente todos os elementos aos quais a aplicamos.

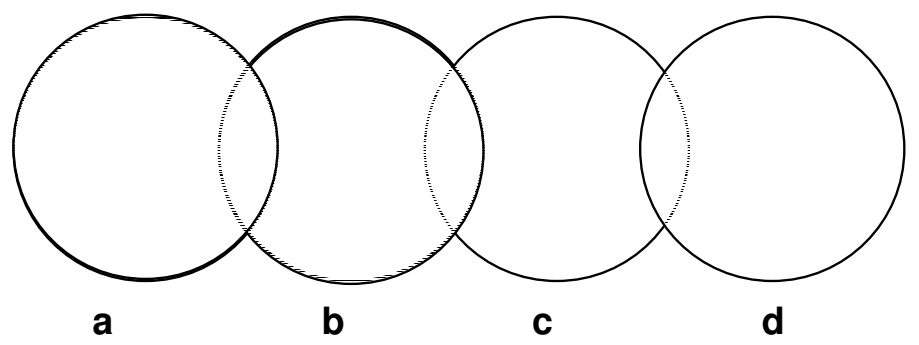

Figura 1 - Modelo de semelhança de família de Wittgenstein (Fonte: CUENCA \& HILFERTY, 1999).

De acordo com a teoria do II Wittgenstein, a proposição (ou termo, ou categoria) passa a ser concebida como uma forma instável de representação, podendo ser revista e reformulada de acordo com os objetivos de comunicação a qual será aplicada.

O II Wittgenstein tem como proposta central avaliar o problema da significação da linguagem, sem, contudo, propor um novo conceito para a questão de categorias. No entanto, é notável observar que o tratamento que ele concede ao problema da linguagem e da significação se ajusta 
perfeitamente a uma nova proposta de representação do mundo, de seus fenômenos tangíveis e intangíveis, ou do entendimento das "coisas do mundo".

A idéia de semelhança de família comporta uma interpretação de encadeamento de entidades cujos atributos são iguais ou semelhantes. Tal idéia sugere uma noção de categorias, embora seja diferente da constituição clássica de categorias que considera os atributos ou propriedades das classes necessariamente iguais e estáveis.

A ruptura proposta pelo II Wittgenstein desafia o padrão clássico inquirindo porque o mundo deveria continuar sendo conhecido e representado por um único modelo. Nesse sentido, a contribuição do II Wittgenstein resulta na alforria das distintas possibilidades de interpretação de mundo por meio do emprego da linguagem e concede à diversidade um lugar ao sol. Dessa forma, são considerados os diversos modos de pensar, as diferentes culturas, classes sociais, etnias, enfim, todas as possibilidades lingüísticas de expressão de mundo são respeitadas, segundo a perspectiva do II Wittgenstein.

\subsection{A CategorizaçÃo sob a perspectiva da semÂntica Cognitiva}

Como já nos referimos na seção anterior, a abordagem do II Wittgenstein foi precursora por desencadear a mudança de paradigma da teoria clássica, sugerindo que as categorias são formadas baseadas na 
semelhança de família, mais do que por definições (similaridades parciais). Wittgenstein indica que a teoria clássica trabalha com limites claros (clear boundaries), definidos por propriedades comuns (common properties) dos membros da categoria. Wittgenstein exemplifica seu modelo com as variações em jogos, que não são categorizados juntos porque não possuem um conjunto de propriedades comuns, mesmo que exista semelhança de família entre eles. Mas aponta o 'melhor' e o 'pior exemplo' que, assim como a semelhança de família, concebe como fatores determinantes na estruturação da categoria.

Devido à sua indiscutível importância como tema de investigação no mundo contemporâneo, além do campo da Filosofia, a categorização tem também suscitado grande interesse pela Semântica Cognitiva, razão pela qual tem sido foco de investigações nessa área. Vejamos a seguir, a contribuição que a Ciência Cognitiva oferece sobre a questão das categorias.

No Prefácio de sua obra considerada pela crítica como um brilhante estudo que alcançou resultados inovadores para a lingüística e que apresentou um modelo cognitivo baseado no campo da semântica, Lakoff ${ }^{4}$ reconhece a Ciência cognitiva como um novo campo que congrega várias ciências, tais como a psicologia, a lingüística, a antropologia, a filosofia e a ciência

\footnotetext{
${ }^{4}$ George Lakoff é professor de lingüística na Universidade da Califórnia, Berkeley. Coautor, com Mark Johnson, de Metaphors we live by, também publicado pela Editora da Universidade de Chicago, e autor de Irregularity in syntax (Fonte: Folha de rosto da obra da mesma autoria. In: Women, fire and dangerous things [ver indicação completa da fonte na seção Referências deste trabalho]).
} 
da computação, cujo objetivo comum é compreender a estrutura e o funcionamento da mente (LAKOFF, 1987) ${ }^{5}$.

Nessa mesma obra, Lakoff busca responder a questões que definam o que é razão, como extraímos sentido de nossa experiência, o que é um sistema conceitual, como este se organiza, além de questionar seu sentido e o que há em comum no modo como o ser humano pensa.

Em sua abordagem, Lakoff traça um paralelo entre a visão tradicionalista a respeito do 'conhecimento' e da 'verdade' e as mais recentes pesquisas desenvolvidas sobre esses temas. Para ele, assim como a verdade, o conhecimento é relativo, dependendo de compreensão (individual). Essa linha de raciocínio inclui a questão da categorização, intimamente ligada à maneira como compreendemos o universo, motivo pelo qual abordaremos a seguir alguns trechos de sua obra.

Lakoff discorre sobre a importância da categorização conceituando-a genericamente como 'uma forma de razão'. Segundo o autor, a cada vez que olhamos para um objeto e o reconhecemos como uma 'árvore' é sinal que empregamos a categorização nessa ação de reconhecimento daquele dado objeto. Do mesmo modo como olhamos novamente para uma 'árvore' e observamos nela frutos estamos novamente categorizando e afirmando que se trata de uma classe específica de 'árvore', uma 'árvore frutífera'. Qualquer espécie de raciocínio, do mais simples ao mais complexo, nos leva a realizar uma categorização, "sem a qual não

\footnotetext{
${ }^{5}$ Neste trabalho realizamos uma tradução livre do texto de Lakoff (1987).
} 
poderíamos funcionar completamente, seja no mundo físico, seja na vida social ou intelectual (...)" (LAKOFF, 1987, p.6). A categorização é o meio de que "dispomos para ordenar o nosso comportamento: sem ele seríamos incapazes de identificar quaisquer repetições, quaisquer regularidades estruturais ou funcionais e a nossa experiência se tornaria uma sucessividade de atos desconexos" (Ibid., id.).

Lakoff avalia que, de acordo com sua posição filosófica, desde a era de Aristóteles até o II Wittgenstein as categorias eram baseadas no princípio da especulação. A teoria clássica de categorias, segundo ele, não foi resultado de estudos empíricos, nem tampouco assunto de um debate importante. Através dos séculos, simplesmente admitiu-se que as coisas eram categorizadas juntas de acordo com as propriedades em comum como um fundamento consensual para a maioria das disciplinas escolares, seguindo o pensamento aristotélico.

Para Lakoff, até muito recentemente, a teoria clássica das categorias não era nem ao menos considerada como uma teoria. Não se pensava nisso como uma hipótese empírica, mas como uma inquestionável e definitiva verdade.

No entanto, em pouco tempo, tudo isso mudou. Sob sua perspectiva, a categorização tem sido encarada, contemporaneamente, como um fator central, estimulada por estudos empíricos desenvolvidos em uma série de disciplinas, uma delas a psicologia cognitiva, campo no qual Eleanor Rosch 
e sua equipe, através de estudos realizados na década de 70, trouxeram à tona a discussão.

As objeções de Rosch quanto à teoria clássica sobre categoria baseiam-se, predominantemente, em duas de suas implicações, segundo Lakoff:

1. As categorias são definidas somente por propriedades compartilhadas por todos os seus membros, logo, nenhum membro deve ser considerado como melhor exemplo daquela categoria que os demais;

2. Se as categorias são definidas somente por propriedades inerentes de seus membros, então as categorias devem ser independentes das peculiaridades daquele que as categoriza, o que significa que esse ato não envolve assuntos como neuropsicologia humana, movimento corporal humano, e capacidades específicas de compreensão, de representação de imagens e de comunicação eficiente (LAKOFF, 1987, p.7).

Lakoff relata que Rosch observou em seus estudos que as categorias, em geral, possuem 'melhores exemplos' (os "protótipos") e que, contrariamente ao que se preconiza na teoria clássica sobre as categorias e "propriedades inerentes" de seus membros, todas as capacidades humanas específicas influenciam o ato da categorização.

Assim, em vez de considerar as categorias como estruturas estáveis e claramente definidas como faz a teoria clássica, a teoria dos protótipos as concebe como estruturas de atributos (traços) graduáveis e com limites difusos. Os graus de relevância dos atributos dentro das categorias correspondem ao fato de que estas se organizam em torno de um centro cognitivo exemplar, no qual as entidades são ordenadas e também 
incluídas ou excluídas pelos falantes, produzindo o que se conhece como 'efeitos de protótipo' [Prototype effects] (LAKOFF, 1987). Abaixo, na Figura 2, temos a representação gráfica de categoria segundo a teoria dos protótipos sugerida por Rosch:

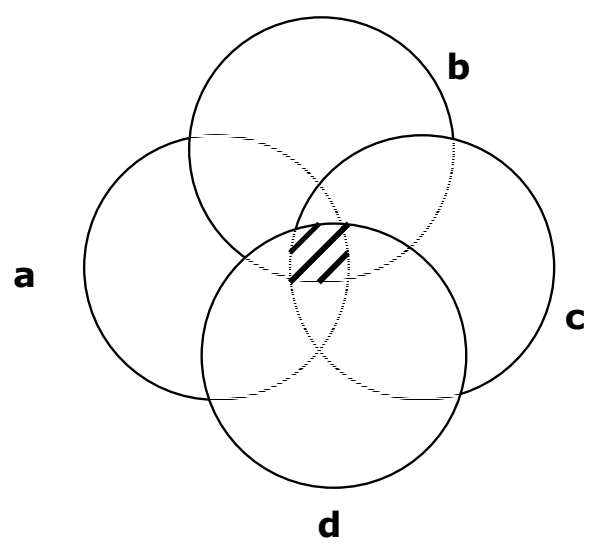

Figura 2- Estrutura interna de uma categoria segundo a teoria dos protótipos

(Fonte: CUENCA \& HILFERTY, 1999).

Para Lakoff, embora os resultados da teoria dos protótipos não devessem causar tamanha surpresa, ainda reverberam nas ciências cognitivas o impacto de suas conseqüências. A teoria dos protótipos estaria alterando a nossa concepção sobre uma das capacidades humanas mais fundamentais - a capacidade de categorizar, bem como o alcance da mente humana e da razão.

A razão, segundo Lakoff, era concebida no passado como algo abstrato, por um lado, diferente da percepção, do corpo e ideais culturais e, por 
outro lado, dos mecanismos da imaginação, como a metáfora e a representação. A abordagem que o autor faz da teoria dos protótipos sugere que a categorização é essencialmente um assunto relacionado, por um lado, à experiência humana e à imaginação, à percepção, à atividademotora, e a ideais culturais; e por outro lado, à metáfora, à metonímia, e à representação. Como conseqüência, a razão depende crucialmente dos mesmos fatores, embora não possa ser caracterizada meramente em termos da manipulação de símbolos abstratos.

Mudar radicalmente o conceito de categoria significa não somente alterar o conceito da estrutura e de compreender o modo de funcionamento da mente, mas implica repensar nossa compreensão sobre o mundo.

De acordo com Lakoff, a teoria dos protótipos (desenvolvida por Eleanor Rosch e sua equipe) alcançou importância graças a estudos intermediários levados a cabo por diversos estudiosos, iniciado com as investigações de Ludwig Wittgenstein sobre o assunto.

As demais teorias que trabalham a questão da categorização (Austin, Zadeh, Lounsdury, Berlin and Kay, Kay and McDaniel, Brown and Berlin, Ekman), apresentadas por Lakoff, são por ele avaliadas como casos especiais, exceto pelos resultados de Eleanor Rosch que forneceu uma perspectiva geral aplicável sobre a categorização, estabelecendo-a como um domínio da psicologia cognitiva. Por meio de uma série de papers, Rosch e associados apresentaram resultados devastadores de suas investigações empíricas que revolucionaram a visão da teoria clássica. 


\subsection{UMA PROPOSTA DA SOCIOLOGIA DO CONHECIMENTO}

Além das interpretações do campo filosófico e da semântica cognitiva sobre a categorização, julgamos necessário incluir a abordagem sociológica de Mauss a respeito da categorização, pois ela propõe reflexões que, ao final, se reconhecerão úteis ao tema desse trabalho. A noção sociológica sobre a categorização nos parece ser uma contribuição à atividade documentária e serve como mais um argumento teórico às demais considerações de outras teorias aqui apresentadas.

Grosso modo, a sociologia pertence a um grupo do que se convencionou chamar por Ciências Sociais. Ao lado de Ciências como a Economia, Antropologia, Ciência Política, História, dentre outras, procura pesquisar e estudar o comportamento social humano em suas mais variadas formas de organização e conflito. Genericamente, poderíamos dizer que seja esse o seu objeto de foco. Não há uma divisão exata entre o objeto destas Ciências, os complexos fenômenos da vida em grupo, em sociedade; freqüentemente utiliza-se de conceitos que perpassam por todas elas. No entanto, compreende-se que cada uma possui métodos e busca objetos específicos.

Numa reflexão de Marcel Mauss (1872-1950), sociólogo e antropólogo francês, a sociologia é uma "ciência dos fatos", distinta, por exemplo, da psicologia, cujos objetos são, segundo ele, as representações individuais, enquanto que na ciência social os objetos são as representações coletivas 
de caráter autônomo e inconsciente para o próprio indivíduo que as possui (MAUSS, 2001).

Mauss estudava fenômenos na sua estrutura própria aos quais denominava "fatos sociais totais" que, segundo ele, possuem implicações simultaneamente em vários níveis da realidade social e em diferentes dimensões dessa mesma realidade.

Dentre os diversos estudos desenvolvidos por Mauss sobre como se organizam e se relacionam em seus mundos os povos primitivos e mais próximos de nós no tempo, nota-se uma semelhança quanto ao fato de que há um vínculo estreito, e não uma relação acidental, entre os sistemas sociais e seus respectivos sistemas lógicos. Por essa razão, Mauss aprofundou suas investigações sobre a mentalidade arcaica e as categorias coletivas de pensamento.

Mauss afirma que, antes de tudo, para explicar um rito ou um mito, antigo na maioria das vezes, e até mesmo um traço do folclore indo-europeu, a sociologia busca compreendê-lo "mostrando as idéias que lhe são subjacentes ou antecedentes" (MAUSS, 2001, p.385). Essa concepção é empregada para esclarecer a confusão existente entre o mito da 'identidade da alma' e do 'nome' na organização social, reflexão que resulta na noção de identidade. Não só sociologicamente, bem como histórica e antropologicamente, entende-se essa questão como um esforço para explicar a origem da representação e do significado do mundo como resultado dela mesma. 
Mauss reforça a sua certeza de que em torno do signo há uma comunhão social e não somente a face lógica da representação coletiva da seguinte forma:

(...) em toda a língua, em todo o símbolo escrito ou não, figurado ou não figurado, pensado ou mesmo apenas subconsciente, em toda maneira de agir e de pensar - e todos supõem no homem a vida em comum - há sempre ao lado de uma lógica imposta, prévia, às vezes animista, outro valor. É um valor "comum", pois quem diz símbolo, diz significação comum para os indivíduos - naturalmente agrupados - que aceitam este símbolo, que escolheram mais ou menos arbitrariamente, mas com unanimidade, um rito, uma crença, um modo de trabalho em comum, um tema musical, uma dança. Em todo o acordo há uma verdade subjetiva e uma verdade objetiva; e em toda a seqüência de acordos simbólicos, um mínimo de realidade, a saber, a coordenação destes acordos. E mesmo se símbolos e cadeias de símbolos só correspondem ao menos às pessoas que as compreendem e nelas crêem, e para as quais servem de expressão total concomitantemente destas coisas e de suas ciências, de suas lógicas, de suas técnicas ao mesmo tempo que de suas artes, de sua afetividade (MAUSS, 2001, p.397).

A argumentação sociológica de Mauss referente à questão da categorização, que acredita coletiva, é suficientemente forte para conjugar o seguinte:

(...) multiplicidade das categorias, multiplicidade dos valores simbólicos, e não simplicidade: eis, em nossa opinião, o ponto de partida. (...) Mas por onde caminhou esse pensamento, em que meio real? Aqui é que se julga de fato necessária a intervenção da sociologia. Nos indivíduos? Na cadeia dos indivíduos? Estes não são mais do que os seres discretos, as multidões onde as coisas se passam. Por conseguinte, os dados psicológicos são os do possível mental. Eles não têm força nem permanência. Aquilo que os realiza, aquilo que Ihes dá forma e matéria, aquilo que os particulariza - que faz, por exemplo, com que o chinês e as línguas polinésias pensem tudo sob a forma do sexo, e não tenham palavra, artigo, pronome para exprimi-lo, ao passo 
que a maior parte das línguas indo-européias conhecem os gêneros, mas não pensam mais nas hierogamias de seus astrólogos e alquimistas - aquilo que categoriza, digo, são as sociedades e sua história. A intradutibilidade das línguas, a das mentalidades traem a heterogeneidade das sociedades, das famílias de povos, das áreas e das camadas de civilização. As categorias vivem e morrem com os povos e seus diversos contributos (MAUSS, 2001, p.396) (grifo nosso).

Assim, o entendimento de Mauss sobre a representação coletiva aplica-se aos métodos do pensamento científico, denominados pelo autor como "instituições sociais", que são explicadas e descritas pela sociologia.

Segundo o autor, os métodos científicos utilizam-se da "função classificadora", abundantemente estudada pelos psicólogos e pelos filósofos, porém, sob prismas diversos.

A classificação, para o autor, consiste em ordenar os seres, os acontecimentos, os fatos do mundo em gêneros e espécies, subordinandoos uns aos outros e determinando as suas relações de inclusão e de exclusão.

Conforme Mauss, para os psicólogos a classificação é entendida como um jogo de associação de idéias, das leis de contigüidade e de semelhança entre os estados mentais, elementos que bastam para explicar a aglutinação das imagens, sua organização em conceitos, classificados uns em relação aos outros. 
A noção de classificação para os filósofos, segundo Mauss (2001), considera a hierarquia dos conceitos como dada nas coisas e imediatamente exprimível pela cadeia infinita dos silogismos.

No entanto, Mauss admite que tais interpretações da função classificadora, ou do ato de "classificar coisas" dadas por filósofos e psicólogos, têm origem na filosofia aristotélica, assumidamente a primeira que "proclamou a existência e a realidade das diferenças específicas, que demonstrou que o meio era causa e não havia passagem direta de um gênero a outro" (MAUSS, 2001, p.400). Novamente, Mauss recorre a uma explicação histórica, colocando em prática o que já havia anunciado antes: é preciso buscar as origens históricas das questões, as suas causas, mostrando que também a noção atual de classificação tem sua história.

Contudo, Mauss rebate a mentalidade que subsistia sobre um limite exato entre uma categoria e outra. Dessa vez, aplica a concepção sociológica, exemplificando os hábitos, crenças e costumes de comunidades orientais e até mesmo na Grécia e Roma Antiga, para demonstrar que é nas metamorfoses, nos ciclos divinatórios ou naturais, assim como nas transformações que se percebe uma passagem entre uma categoria e outra, de um estado de coisas para outro.

Embora a proposta de Mauss não seja recente (1920), a riqueza de suas considerações referentes à representação coletiva soam contemporâneas, porque parecem considerar todas as transformações técnico-científicas que a humanidade experimentou até os tempos atuais, incluindo as 
conseqüências decorrentes do crescimento e diversidade da comunicação técnico-científica e às tentativas de propor formas para sua organização. Assumir tais considerações requer levar em conta que para compreender as coisas do mundo, relacionar-se com ele, produzir conhecimento, não se pode prescindir do reconhecimento de que as categorias coletivas se relacionam estreitamente com os "fatos sociais" locais.

Mauss preconizou os seus ideais sociais de forma brilhante, mostrando que os estudos da sociologia permitem esclarecer que o funcionamento das operações lógicas não se descola do funcionamento social. Essa é uma das principais contribuições do seu pensamento à compreensão dos processos de categorização atuais. 


\subsection{O ENTENDIMENTO de CATEgoria Na Biblioteconomia e NA CI}

O propósito desse capítulo é verificar como alguns dos principais autores clássicos da área da Biblioteconomia e da CI concebem a categorização. Pretende-se com essa análise, amealhar contribuições, mesmo que iniciais, para o aperfeiçoamento das metodologias de construção de linguagens documentárias, uma vez que não se pode desconsiderar os conhecimentos daí resultantes como respaldo às teorias atuais sobre a organização e categorização da informação.

No campo documentário, a categorização se expressa na representação da informação como "agrupamentos que manifestam freqüentemente particularidades em relação às áreas do conhecimento, às aplicações pretendidas pela linguagem documentária ou ao tipo de informação a ser organizada" (SMIT et.al., s.d.). Podemos afirmar que o primeiro nível de organização entre os termos é expresso pelas categorias, que irão delinear a hipótese de organização da informação a ser explorada pela LD. Nas práticas documentárias a categorização tende a mostrar seu uso 
aplicado na forma de campos temáticos no interior de domínios de especialidade ou de atividade, como se pode observar, por exemplo, nos tesauros.

No entanto, verifica-se que a literatura apresenta certa imprecisão terminológica, uma vez que, ora faz referência à "categorização", ora se faz menção à "classificação" para indicar processos semelhantes.

Essa variação terminológica foi discutida por Jacob (2004, p.526) que realiza um exame das propriedades sistêmicas e formas de interação que caracterizam a classificação e a categorização, revelando diferenças sintáticas fundamentais entre a estrutura do sistema de classificação e a estrutura do sistema de categorização, ambos mecanismos para organizar a informação, porém diversos quanto à possibilidade de organização de entidades.

Jacob (2004) afirma que, embora existam similaridades óbvias entre classificação e categorização, as diferenças entre elas têm implicações significativas para a constituição da informação contextualizada que, segundo a autora, são "diferenças que fazem diferença". As dificuldades para distinguir entre esses dois sistemas de organização decorrem da confusão conceitual entre os termos, reforçada pelo fato de que tanto classificação, como categorização são mecanismos para organizar informação. Em verdade, a diferença entre os dois sistemas é bastante tênue. 
A literatura sobre categorização é permeada com passagens onde os termos "classificação" e "categorização" são usados indiscriminadamente para indicar o mesmo processo. Jacob cita Rosch e outros (1976) que fornecem um exemplo ilustrativo de como esses dois termos são usados indiscriminadamente:

(...) o objetivo da categorização é reduzir as infinitas diferenças entre estímulos para proporções utilizáveis comportamentais e cognitivas. É vantagem para o organismo não diferenciar um estímulo dos outros quando a diferenciação não for relevante para os propósitos de interesse. O nível básico de classificação, o nível primário no qual os cortes que são realizados no contexto, parece resultar da combinação desses dois princípios; a categorização básica é o nível mais geral e inclusivo no qual as categorias podem delinear estruturas correlacionais do mundo real (ROSCH citada por JACOB, 2004, p.551) (Tradução livre da autora).

Essa falta de distinção entre "categoria/categorização" e "classe/classificação", segundo Jacob (2004), ocorre com freqüência pelo uso de conceito de classificação como sinônimo de categoria (GARDNER citado por JACOB, 2004). Infelizmente, essa imprecisão terminológica obscurece as discussões, porquanto os pesquisadores lidam indistintamente com conceitos similares, mas não idênticos.

Embora as operações de classificação e categorização sejam mecanismos de ordenação para estabelecer ordem por meio de fenômenos agrupados e relacionados, diferenças fundamentais entre eles influenciam como tal ordem é efetivada. Para Jacob (2004), essas diferenças fazem a diferença na informação contextualizada estabelecida por cada um desses sistemas. 
Jacob (2004) entende que, enquanto a classificação tradicional é rigorosa no que se refere aos critérios estabelecidos para que uma entidade possa ou não ser membro de uma classe determinada, o processo de categorização é flexível e criativo e delineia associações desordenadas entre entidades - associações que são baseadas não num conjunto de princípios predeterminados, mas sim no simples reconhecimento de similaridades que existem entre um conjunto de entidades. A classificação divide o universo de entidades num sistema de classes arbitrário e desigual cujo arranjo dentro do contexto conceitual é definido por um conjunto de princípios estabelecidos. O fato é que nem o contexto e nem a composição dessas classes alteram as bases para a estabilidade de referência dada por um sistema de classificação. Em comparação, a categorização divide o mundo da experiência em grupos ou categorias cujos membros sustentam algumas semelhanças imediatas dentro de um dado contexto.

Tal imprecisão terminológica entre a "classificação" e a "categorização" na Biblioteconomia e CI pode também ser entendida pela própria evolução de sua aplicação na Biblioteconomia no decorrer do tempo. Dada a essa imprecisão, muitas vezes a categorização é discutida a partir da Teoria da Classificação. Na perspectiva que preferimos adotar, a classificação é um processo que pressupõe a distribuição de elementos segundo características tomadas como padrão; a categorização é um procedimento focado nas propriedades atribuídas a um termo que se refere a um objeto ou fenômeno. 
Autores como Shera, Grolier, Vickery, Fonseca e Dahlberg, trabalham a questão da organização sob o ponto de vista da Teoria da Classificação, nem se referindo, de modo explĩcito, à categorização, embora ela possa estar subentendida. Compreende-se, desse modo, porque a questão da categorização não é formulada de modo claro na literatura clássica da Biblioteconomia e da CI.

\subsection{A visão de autores classicos dA Bibloteconomia sobre A CATEGORIZAÇÃo}

\subsubsection{Sistematizações de Shera, Vickery, Dahlberg e Fonseca}

Conforme já registramos no Capítulo anterior, ainda que contemporaneamente a categorização seja assumida, ou como parte da capacidade intelectual necessária ao ser humano para a efetivação do processo cognitivo, ou como expressão sócio-cultural de organizar o mundo, de um modo geral, ela não tem sido reconhecida como uma questão presente nos discursos contemporâneos da Ciência da Informação. Nota-se que, assim como o desenvolvimento natural de qualquer tema científico, o assunto atravessou o tempo encontrando algumas respostas, se expressando como dúvida, sobretudo assumindo, ao menos implicitamente, pressupostos de determinadas doutrinas 
filosóficas que podem ser reunidos sob o título de Teoria da Classificação, termo hoje em desuso.

Autores como Shera, Grolier, Fonseca, Vickery e Dahlberg realizam, geralmente, uma retrospectiva histórica, procurando encontrar as raízes fundamentais da organização da informação. Nessas pesquisas, há indícios que apontam para uma correlação entre o volume de informação gerada, o grau de especialização das ciências e o nível de aprofundamento dos sistemas de organização da informação.

Alinhando-se aos autores que trabalham as questões da organização (e, de modo subjacente, a categorização) na perspectiva da Teoria da Classificação, Piedade (1977), assim como muitos autores clássicos, procura, primeiramente, definir o que é classificação:

A classificação, entendida como processo mental de agrupamento de elementos portadores de características comuns e capazes de serem reconhecidos como uma entidade ou conceito, constitui uma das fases fundamentais do pensar humano (ASTÉRIO DE CAMPOS citado por PIEDADE, 1977, p.8).

Um Sistema de Classificação ou Tabela de Classificação seria algo correlato, pois para ela consiste num conjunto de classes apresentadas em forma sistemática compondo um conjunto de idéias distribuídas num determinado conjunto de conjuntos parciais, coordenados e subordinados (PIEDADE, 1977). 
Para compreender o que são categorias, Piedade faz um apanhado de várias definições de autores clássicos, quer da Filosofia ou da área de Biblioteconomia, conforme segue:

(...) as categorias são fatos que constatamos nas coisas, quando as examinamos. São as principais entidades envolvidas na estrutura da realidade, modos de ser a serem reconhecidos, formas de existência que compõe a existência de todas as coisas (Aristóteles).

(...) "as leis primárias e as relações fundamentais que determinam a forma de conhecer" (Renouvier).

(...) "conceitos de alta generalização e grande aplicação elaborados pelo espírito, ao se referir direta ou indiretamente ao conhecimento empírico e utilizados por ele para interpretar esse conhecimento" (L. Wood e B. S. Vickery).

(...) "um conceito de alta generalização e de grande aplicação, que pode ser empregado para reunir outros conceitos. Ex.: na categoria Lugar, podemos distinguir as facetas: Lugar Físico, Lugar Político, Orientação (norte, sul, etc.) (Jack Mills).

(...) "em classificação reserva-se o termo categoria para as classes mais gerais de fenômenos" (Landridge) (VICKERY, 1980, p.11-12).

Como sistematização resultante de sua peregrinação bibliográfica, Piedade afirma que as "categorias são as grandes classes, os grandes tipos de fenômenos presentes no conhecimento em geral ou numa de suas partes" (PIEDADE, 1977, p.12). Verifica-se, pela proposta, que a autora não define, de fato, uma categoria, antes dá exemplos de suas manifestações.

Vickery (1980), por sua vez, afirma que cada época transcorrida reflete, em suas respectivas classificações do conhecimento os seus problemas particulares, seus métodos de estudo, seu modo especial de pensamento 
que serviu como estrutura para suas teorias, bem como seus interesses intelectuais dominantes. O autor não fala em categoria, mas relaciona modos de organização aos pensamentos de cada época:

Uma organização do conhecimento que se adapte às filosofias dos gregos, não se adapta às cosmologias mitológicas da Babilônia, à vida impetuosa da Renascença, ou ao industrializado século XIX. Na verdade, quanto mais uma classificação se adaptar a uma determinada época, menos adequada será para qualquer outra (VICKERY, 1980, p.187).

A preocupação com a história da classificação está presente em diversos autores da área, que a relacionam, invariavelmente, com o estudo do conhecimento.

Na retrospectiva feita por Dahlberg a autora afirma que, na Antigüidade, a classificação do conhecimento era considerada uma arte (1972), sendo aplicada de diversos modos segundo o desenvolvimento do conhecimento humano. O arranjo sistemático já é algo presente na composição de trabalhos de muitos filósofos da Antigüidade - Indic Vedas, Amenope (1250 A.C.), Caius Plinius Secundus (23-79 D.C.), antecessores de Aristóteles.

Para Vickery o interesse em estudar o conhecimento teve origem com os filósofos gregos, dentre os quais se destaca Platão, que descreveu as ciências como instrumentos da cultura capazes de transformar o filósofo num perfeito administrador do estado (VICKERY, 1980). Posteriormente, Aristóteles propôs alterações da divisão do conhecimento elaborada por 
Platão, sob um ponto de vista mais amplo, sendo que sua proposta de classificação do conhecimento perdurou por quase dois mil anos, embora sua síntese fosse pouco conhecida durante a Idade Média na Europa, período no qual se inicia a sua decadência.

Para Shera (1957), a classificação de Aristóteles (382-322a.C.) merece destaque, pois foi adotada como modelo para a classificação bibliotecária até meados do séc.XX. O autor destaca o fato de que Aristóteles se baseou num conceito de realidade particular, no qual o mundo físico é expresso em termos de um conjunto de características abstratas reunidas num todo individualizado, que somado, se torna a coisa real em questão. Segundo Shera (1957), deriva daí a ciência da classificação de Aristóteles em gêneros, espécies e sub-espécies, que encontra respaldo na ciência de 'Divisão' de Platão. Lembra o autor, que a doutrina aristotélica da Predicação e Substância Primária consideram conceitos uma conjunção de atributos e disjunção de substâncias primárias.

Vickery lembra que na Idade Média, Roma teve pouco a acrescentar em relação às classificações antes propostas, embora tenha gerado grandes pensadores. Em função do declínio de Roma, a herança da ciência grega passou principalmente para os povos de língua árabe. Entretanto, é notório acrescentar que nesse período surge a distinção entre o que passou a ser conhecido como ciências puras e aplicadas, que também ocorreu entre as ciências "teóricas" e as "artes" (VICKERY, 1980). Já Dahlberg ressalta que os grandes filósofos da Idade Média - Isidro de 
Sevilla, Vincent de Beauvais, Bartholomaeus Anglicus, Brunetto Latini, seguiram o modelo da síntese aristotélica (DAHLBERG, 1972).

Ao final da Renascença, período compreendido entre 1400-1700, há vestígios da decadência do modelo aristotélico, segundo Vickery (1980). Nesse período surgem as novas propostas de classificação de Conrad Gesner (1548). Mesmo que em seus escritos Gesner atacasse freqüentemente Aristóteles, com o qual afirmava estar em desacordo teórico, os agrupamentos básicos da Física e da Matemática aristotélica, por exemplo, pareciam exatamente os mesmos na classificação baconiana. Outro filósofo que merece destaque nesse período foi Thomas Hobbes que publicou Leviathan (1651), obra na qual manteve a mesma interpretação teórica proposta por Aristóteles.

Outro aspecto lembrado por vários dos autores citados são as relações entre as classificações filosóficas e as classificações bibliográficas.

Segundo Shera (1957), a preocupação em construir e aperfeiçoar novos sistemas para a organização do conteúdo de coleções de livros também remonta à Antigüidade, fonte de inspiração dos bibliotecários da época que teve origem nos trabalhos filosóficos de então. Contudo, é preciso assinalar as diferenças entre 'classificações bibliográficas' e 'classificações filosóficas'. 
Essas distinções já eram observadas há sessenta anos por Hulme ${ }^{6}$ com base nas suas distintas funções. Hulme observa que a divisão e coordenação das classes em literatura "é determinada principalmente em linhas formais e não filosóficas" (HULME citado por VICKERY, 1980, p.205). A classificação de documentos era "o esboço de áreas préexistentes em literatura" (Ibid., p.205), e a coincidência com uma ordem filosófica não trazia consistência aos esquemas, já que não era garantia de exatidão.

A questão é também apontada por Fonseca (1976) que, em sua palestra na Conferência Brasileira de Classificação Bibliográfica realizada no Rio de Janeiro em 1976, explora a classificação em busca de um consenso, assinalando como curiosidade a íntima ligação entre as 'classificações bibliográficas' e as 'classificações filosóficas', que considera diametralmente opostas. Para o autor a classificação bibliográfica não pode se limitar a ser eminentemente prática - nominalista - nem tampouco violentar a filosofia, assumindo um tom exageradamente realista.

Em verdade, a classificação filosófica foi válida para os livros enquanto o volume de literatura registrada era pequeno e a quantidade de publicações consistia em tratados sistemáticos que davam interpretação de um campo como um todo, ou enquanto os estudos monográficos abrangiam a totalidade de um sub-tópico que era ele mesmo parte

\footnotetext{
${ }^{6}$ Trata-se de HULME, E.W. (1950) citado em VICKERY (1980).
} 
integral de uma unidade maior (SHERA, 1957). Sendo assim, não se discutia a aplicabilidade da classificação de assuntos para a classificação dos livros.

Notadamente, até então, a ciência se encontrava em estado quase embrionário de evolução. Porém, à medida em que se desenvolveu, essa inadequação na aplicação da classificação de assuntos em coleções de livros se aprofundou e transpareceu. Nesse sentido, Grolier afirma que "não há ciência sem classificação dos fatos que ela estuda; e as classificações progridem com as ciências que as elaboram" (GROLIER citado por FONSECA, 1976).

Parafraseando Jevons, Fonseca reconhece que a classificação de livros é tanto mais complicada que a classificação por assuntos "porque o mesmo livro pode tratar de diferentes ciências, ou pode discutir um problema que envolve muitos campos do conhecimento" (JEVONS citado por FONSECA, 1976). Assim, a concepção de Jevons identifica perfeitamente o que mais tarde seria reconhecido como 'interdisciplinaridade':

Um bom trabalho sobre máquina a vapor ficará antiquado, na medida em que deixe de investigar os primeiros esforços para sua descoberta: puramente científico, quando se considera os princípios de termodinâmica nela implícitos; técnico, quando se atenta para os meios mecânicos de aplicação de tais princípios: econômico, quando se julga os resultados industriais da invenção; biográfico, quando se destaca as vidas dos inventores. A história da Abadia de Westminster pode pertencer, igualmente, à história da arquitetura, à história da Igreja ou à história da Inglaterra. Se abandonamos a tentativa, procurando estabelecer um arranjo de acordo com a classificação natural das ciências, formando amplos grupos práticos, ficaremos continuamente perplexos diante da ocorrência de casos intermediários, 
diferindo as opiniões tão ad infinitum quantos sejam os detalhes (JEVONS citado por FONSECA, 1976).

Ainda que reconhecendo que as classificações filosóficas não podem ser aplicadas às classificações de livros, não se pode deixar de buscar racionalmente os motivos que expliquem tal fato. Como tentativa para encontrar respostas ao problema, Hulme sugeriu que "enquanto os termos [técnicos] forem retirados [da classificação da ciência] para compor um livro, esses termos não são mais considerados como 'distinções expressas' de valor científico real" (HULME citado por VICKERY, 1980) (sic da autora). O que Hulme tenta demonstrar é que existe um conflito entre "garantia literária" e "classificação lógica", que o conflito real está entre conceitos velhos e os novos no assunto classificado. Hulme pondera que dependendo do período no qual livros foram elaborados, os seus conteúdos nem sempre se ajustam às classificações que, por sua vez, também foram produzidas em época diversa. É um indicativo de que as classificações não acompanham o desenvolvimento ou a progressão alcançada de determinado assunto, porque são sistemas herméticos e previstos para atender a uma determinada época, baseada num determinado estado de evolução do conhecimento.

As discussões sobre classificação se dão, também, em torno de propostas específicas, como a formulada por Ranganathan, que acabou inaugurando uma nova fase na história da Teoria da Classificação. Dada sua importância sobre a categorização, sistematizaremos, a seguir, 
observações feitas pelos autores selecionados. Observa-se que, com a Colon Classification, de Ranganathan, passa-se a observar melhor a possibilidade da combinação de aspectos de um assunto, ou de conceitos simples para a formação de conceitos complexos, o que certamente terá influências no conceito de categorização do ponto de vista pragmático.

A possibilidade de ampliar as combinações de assuntos e de buscar consistência para uma classificação bibliográfica foi o que motivou Shiyali Ramamrita Ranganathan (1892-1972) a elaborar a Colon Classification, também conhecida como Classificação dos Dois Pontos, Classificação Facetada ou Classificação Analítico-Sintética (PIEDADE, 1977). O conjunto da obra de Ranganathan é amplamente reconhecido, e a respeito da Colon Classification Palmer certa vez escreveu:

(...) é um sistema que tem futuro, não necessariamente no sentido de que seja provável a sua adoção em larga escala, mas no sentido de que será o germe de futuros sistemas, que ofereçam esperança de superar a produção de conhecimentos, que cresce diariamente (PALMER citado por PIEDADE, 1977, p.158).

Como previu Palmer, a Classificação dos Dois Pontos fundamentou as classificações facetadas elaboradas posteriormente, conforme registro de Dahlberg (1972). Até então, os sistemas de classificação se resumiam nas classes principais, classes básicas, tabelas auxiliares, etc., que eram consideradas como elementos básicos de um sistema. Segundo Dahlberg (1972), Ranganathan mudou o sentido de sistemas de classificação que, de apresentação sistemática de classe, passam a focar os conceitos 
relativos a objetos (coisas, fenômenos, processos, acontecimentos, atributos, etc.).

A afirmação acima se confirma quando, numa referência à Colon Classification, Vickery (1980) afirma que Ranganathan demonstrou que o número de assuntos específicos que devem ser selecionados numa classificação é potencialmente infinito: entre dois pontos no sistema deveria ser inserido um número indefinido de novos pontos. Nesse sentido, para Ranganathan o conhecimento é multidimensional e não respeita uma única direção, mas sim considera que cada assunto é uma síntese de vários conceitos múltiplos ligados. A idéia sempre presente na teoria de Ranganathan é a de que "agrupamento" existe quando dois "universos de raciocínio, cada um infinito e completo em algum sentido definível, devem ser considerados em relação uns com os outros" (VICKERY, 1980, p.210). Ainda citando Vickery, Ranganathan contou com o auxílio de Puranik que:

numa análise de assunto de cinco periódicos diferentes durante 50 anos, evidenciou que enquanto em 1900 mais da metade dos assuntos da amostra consistia de conceitos "simples", em 1950 mais de 85\% eram compostos mostrando laminação ou agrupamento (VICKERY, 1980, p.210).

Tal demonstração contribuiu para que Ranganathan projetasse um sistema de classificação no qual os assuntos fossem estruturados sinteticamente a partir de conceitos "elementares". Dessa forma, Ranganathan partiu para a construção da Colon Classification baseando-se 
num "universo" de entidades (seres concretos e conceituais), no qual cada entidade possuía muitos atributos, que por sua vez poderiam servir como características para a divisão do universo em grupos ou classes.

Para Dahlberg (1979), a metodologia de Ranganathan foi fortemente influenciada por sua formação matemática e pelas crenças no misticismo, marca da cultura hindu. Seu sistema era caracterizado pela abordagem analítica e combinatória e empregava o método das facetas e análises de facetas, possibilitando a criação de classes de livros somente no momento em que um livro era analisado segundo os elementos conceituais de seu assunto, e, posteriormente, sintetizado segundo as regras das fórmulas de facetas ligadas às disciplinas. Para Dalhberg (1979) a primeira contribuição importante para a nova Teoria da Classificação foi a identificação de três planos distintos com os quais se trabalha num processo de classificação: o "plano da idéia", no qual ocorre a formação dos conceitos, o "plano verbal" relacionado com a expressão verbal dos conceitos, e o "plano notacional" compreendido pela utilização de sinais, letras e números para a fixação dos conceitos. Nesse sentido, a contribuição de Ranganathan foi fundamental para caracterizar o conceito único e sua capacidade de combinação para representar o conhecimento que o homem tem do mundo, como objeto da ciência da classificação. A segunda contribuição de Ranganathan compreende o uso de "facetas" (categorias desenvolvidas de acordo com a natureza dos conceitos) para realizar a representação do assunto de acordo com a LD adotada. As "facetas" ou "categorias" adotadas por Ranganathan são "Personalidade, 
Matéria, Energia, Espaço, Tempo", seqüência que corresponde à fórmula "PMEST". A utilidade reconhecida pelo emprego das categorias garante a consistência do sistema de conceitos em determinada disciplina e tem como finalidade a representação dos assuntos e a ordenação dos conceitos de uma disciplina em classes formais. Outra importante contribuição de Ranganathan é reconhecida pelos seus 18 princípios $^{7}$ para o arranjo de elementos das facetas de uma maneira repetível; são seus "princípios para seqüência útil considerados como um instrumento proveitoso para a avaliação de sistemas de classificação" ${ }^{\prime 8}$ (DAHLBERG, 1972).

Embora Ranganathan tenha partido da CDD para propor uma reformulação da Teoria da Classificação, a mudança provocada pela sua Classificação dos Dois Pontos soou como o marco de uma nova era, a partir da qual foi possível libertar a classificação da rigidez do pensamento e sugerir um instrumento potencialmente flexível, capaz de otimizar a recuperação da informação. A importância do legado de Ranganathan é

7 Segundo Piedade, para que se atinja a seqüência útil, Ranganathan introduziu os princípios abaixo:

1. Cânone de extensão decrescente (Cânon of decreasing extension);

2. Princípio da Concreção crescente (Principle of increasing concreteness);

3. Princípio de prosperidade na evolução (Principle of later in evolution);

4. Princípio da posteridade mo tempo (Principle of later in time);

5. Princípio da contigüidade espacial (Principle of spacial contiguity);

6. Cânone de consistência na seqüência (Cânon of consistent sequence);

7. Princípio da seqüência canônica (Principle of canonical sequence);

8. Princípio da complexidade crescente (Principle of increasing complexity);

9. Apelo às leis da Biblioteconomia.

"As Cinco Leis da Biblioteconomia determinam que a biblioteca deva servir exatamente, exaustivamente e rapidamente ao leitor, com o menor esforço e o menor desperdício de recursos humanos" (Gopinath) (PIEDADE, 1977, p.76).

8 Embora Piedade se refira a 9 princípios, Dahlberg (1972) relaciona 18 princípios, conforme se pode ver nesta página deste trabalho. 
compreendida pelo fato de que, para ele o universo do conhecimento não era estático, mas

um contínuo dinâmico. Sua estrutura está, portanto, sempre mudando. Por essa razão não é suficiente conhecer sua estrutura no momento. Deveria também, compreender seu modo de desenvolvimento (RANGANATHAN citado por VICKERY, 1980, p.213).

O investimento de Dahlberg, que certamente se deve, também, às reflexões de Ranganathan, culmina numa proposta própria que é bastante significativa no âmbito da Teoria da Classificação e, de modo derivado, fundamental para os estudos sobre categorização. Partindo da constatação de que um sistema de classificação denota ordenação, que tanto pode ser relativa a elementos naturais (de documentos) quanto a conceitos, Dahlberg formula as bases da teoria do conceito. Em inúmeros trabalhos, a autora se dedica a apresentar sua teoria, cuja particularidade é colocar, não mais o 'assunto' como elemento central da classificação, mas o 'conceito', ou 'conceitos', que o compõem. Por meio da proposta, é possível se aproximar mais da idéia de categoria, até então embrionariamente colocada.

A autora reconhece os conceitos como elementos dos sistemas de classificação, que podem assumir o caráter de classes inteiras de acordo com as características dos objetos de seus membros, na medida em que tais objetos estiverem contidos nos conceitos de um sistema de classificação. 
Segundo Dahlberg (1979), podemos nos referir a objetos individuais quando os mesmos são pensados como únicos e caracterizados pelas formas do tempo e espaço, ou seja "a priori", numa clara referência à linguagem kantiana. A autora faz menção também aos objetos universais, que de certo modo, dispensam as formas de tempo e espaço e correspondem aos conceitos gerais. Com os conceitos individuais e os conceitos gerais, é possível elaborar enunciados que são a base para se estabelecer conceitos relativos aos objetos. Assim, Dahlberg (1979) considera que cada enunciado verdadeiro representa um elemento do conceito. A formação dos conceitos é, portanto, definida como a reunião e compilação de enunciados verdadeiros a respeito de determinado objeto, processo denominado 'análise do conceito'. Para Dahlberg, o conceito é a unidade de conhecimento que compreende afirmações necessárias e verificáveis sobre um referente representado por uma designação.

A concepção de categoria decorrente se relaciona à ocorrência de características comuns em diversos membros, ou seja, o conceito na sua mais ampla extensão.

\subsubsection{O relatório de Grolier sobre as categorias}

Um dos primeiros (e talvez único e sistemático) estudos sobre as categorias utilizadas na Documentação foi feita por Éric de Grolier, em 1962, a pedido da UNESCO. O documento por ele elaborado, sob o título 
'Étude sur les catégories applicables aux classifications et codifications documentaires' ${ }^{\prime 9}$ relata as transformações na estrutura das classificações e 'codificações documentárias' ocorridas depois da II Grande Guerra, com a utilização de meios mecânicos, eletro-mecânicos e eletrônicos. Grolier salienta que as alterações principais se deram em torno da decomposição de assuntos complexos em fatores simples, à passagem das classificações fortemente hierarquizadas aos sistemas mais flexíveis e à tomada de consciência de não se restringir à expressão dos termos elementares, mas das relações entre eles.

A solicitação da UNESCO feita a Grolier partiu do princípio de que seria necessário contar com uma proposta normalizada de classificação que partiria da observação das diferentes codificações e classificações existentes em diferentes domínios do conhecimento. A demanda da UNESCO foi debatida em vários fóruns, geralmente convocados pela entidade, que aconteceram entre 1949 e 1957, quando, seguindo também recomendações da FID, se recomendou realizar

um estudo das categorias suficientemente gerais para serem utilizadas nas classificações ou codificações de diferentes domínios do conhecimento - conceitos lógicos e morfológicos, espaço e tempo, posição e movimento - e a preparação de um relatório a ser apresentado à Conferência internacional sobre informação científica, em Washington, em 1958 (Documento Unesco NS/148 citado por GROLIER, 1962, p.12).

\footnotetext{
${ }^{9}$ Neste trabalho realizamos uma tradução livre do texto de Grolier (1962).
} 
O trabalho de Grolier se inicia pela identificação de um desejo de construção de uma espécie de 'interlíngua', uma linguagem universal para o tratamento da informação, muito embora houvesse vozes contrárias à concretização dessa possibilidade. Antes de iniciar seu trabalho, Grolier registra uma série de definições e tentativas de precisão terminológica, destacando-se, dentre elas, a noção de 'categoria', sobre a qual se volta nosso interesse principal, que ele reputa ser diversamente compreendida.

O termo categoria é tomado tanto em sentido amplo e geral - como sinônimo de 'ponto de vista' segundo o qual se pode dividir um assunto (Wildhack ${ }^{10}$ ), como sinônimo de faceta (como em Foskett, seguindo o termo em voga proposto por Ranganathan), para sugerir a 'análise por facetas' que constituiria a uma análise de conjunto de um assunto 'sob um certo número de facetas ou categorias das coisas; no interior de cada categoria, as rubricas enumeradas comportariam todas a mesma relação, confrontando com o assunto em seu conjunto (GROLIER, 1962, p.15).

Categoria também é tomada com o sentido de 'conceitos gerais' (na acepção adotada no Vocabulaire de la philosophie de Lalande e conforme o 'Glossary and subject index', ${ }^{11}$ ) referindo-se a um 'conceito de alto grau de generalidade que tem um largo domínio de aplicação que pode ser utilizado para agrupar outros conceitos' (GROLIER, 1962, p.16). Para Vickery, que toma uma definição utilizada por L. Wood, o termo

\footnotetext{
${ }^{10}$ Para identificação completa do nome dos autores, consultar Grolier (1962).

11 Texto não publicado, divulgado em ed. 'multigraphié', s.d., que constitui uma edição revisada e aumentada do glossário "Indian standards glossary for classification terms, Annals of library science, 5, 1958, p.76-112), conforme citado por Grolier (1962, p.170171).
} 
'categorias conceituais' compreende 'conceitos de alto grau de generalidade que têm amplo domínio de aplicação elaboradas pelo pensamento se referindo direta ou indiretamente ao conhecimento empírico e utilizadas pelo pensamento para interpretar esse conhecimento' (GROLIER, 1962, p.16).

Na terminologia de Ranganathan, mais especializada, segundo Grolier, o termo 'categoria fundamental' é utilizado segundo um sentido particular, para se referir à "cada faceta de um assunto qualquer, como também cada divisão de uma faceta [que] é considerada como uma manifestação de uma das cinco categorias fundamentais" (RANGANATHAN citado por GROLIER, 1962, p.16). Para o autor, essa concepção poderia se ligar às tradições filosóficas ou místicas, mas em Ranganathan elas aparecem ligadas a uma preocupação muito prática de assegurar uma seqüência uniforme das facetas nos diferentes assuntos (RANGANATHAN citado por GROLIER, 1962, p.16).

Apesar de repertoriar as várias acepções do termo categoria, Grolier não adota em seu trabalho apenas uma delas. De modo explícito, ele afirma que não se limita, no relatório, a examinar as categorias fundamentais, como também não escolhe qualquer outro sistema de categorias de base para o agrupamento de 'mots-code' em classes formais, mas examinar, de uma maneira geral, o conjunto dos procedimentos pelos quais, numa codificação usada para a pesquisa de informações contidas em documentos se pode evitar os problemas da simples enumeração de 
termos. Grolier também não se furta a afirmar que seu trabalho não leva a uma conclusão positiva sobre a categorização, restringindo-se ao levantamento de problemas que possam servir de quadro de referência para estudos posteriores (GROLIER, 1962, p.16-17).

Nesse sentido, o trabalho de Grolier percorre várias das classificações e codificações existentes, pontuando o que observa como aspectos mais particulares do que seria uma categorização, a exemplo do que enumeramos abaixo:

\section{- Classificações documentárias enciclopédicas:}

\section{- $C D U, C D D:$}

- adoção de divisões paralelas em seus esquemas, seguindo um princípio de regularidade para evitar a repetição das características sob os assuntos distribuídos no esquema, seja via adoção de símbolos especiais para divisões comuns ou por outras formas de separação dessas características em tabelas especiais;

- indicação de relações gerais, de relações de soma, de pertinência, de orientação ou aplicação, a partir de símbolos próprios ou de separação em tabelas especiais;

- tratamento da noção de espaço sob subclasses específicas dentro das classes que se referem a conhecimentos ou atividades humanas, ou sob forma de subdivisões especiais, aplicáveis mais genericamente (divisões comuns de lugar); 
- tratamento da noção de forma (como noção geográfica - figura geométrica constituída pelos contornos de um objeto; estrutural partes de um todo, unidades autônomas de um conjunto, elementos em solidariedade interna, etc.ou, de modo genérico, morfológica no sentido das várias manifestações formais de um assunto). $\mathrm{Na}$ maior parte dos sistemas, tais divisões não recebem um tratamento uniforme, com poucas exceções;

- tratamento das noções cronológicas por subdivisões à parte dos esquemas;

- tratamento das divisões por línguas, raças, subdivisões comuns de ponto de vista etc.

- subdivisões analíticas (hoje denominadas especiais) permitem tratar de modo separado, aspectos relativos a diversos assuntos dos esquemas, dentre eles, os consagrados à pessoa (por idade, por renda, por raça, por sexo, por profissão etc.), muito embora Grolier afirme ser difícil considerar a noção de pessoa como uma noção verdadeiramente geral, localizando em Psicologia sua melhor aplicabilidade.

Note-se que Grolier não propõe uma distinção entre a CDD e a CDU, mas tal diferenciação é feita, por exemplo, por Lara (2001), que afirma que as operações principais da CDD, voltadas à organização de documentos, mais do que à transferência da informação, estavam focalizadas nas classes, o 
que não acontece sempre com a CDU que, mais preocupada com a função de organização da informação de artigos de periódicos, ao lado das classes, privilegiou os assuntos e as relações entre eles.

Grolier também se reporta a noções filosóficas mais gerais: ser, substância, acidentes, ação, unidade, multiplicidade, verdade, bondade, ou ainda força, energia, quantidade, causalidade, liberdade, necessidade, além das noções de ordem, significação, objetivo, causa, valor, finito, e infinito, alma, vida, morte, além de categorias lógicas, que se encontram tanto na classe Filosofia como em subdivisões de ponto de vista tratadas separadamente.

\section{- Colon Classification (CC)}

As relações aqui encontradas são denominadas, por Ranganathan, de relações de fase ou intra-facetas, que podem se aplicar aos índices de classificação que fazem parte das classes principais. Tais relações compreendem a relação geral, a relação de implicação, a de comparação, de diferença e de influência. As relações principais, no entanto, compreendem as relações de gênero e espécie, coisa e suas partes, matérias constituintes, propriedades e processos. Como na CDU, prevalece na CC a relação hierárquica ou de inclusão, sendo que o universo de conhecimentos e atividades é dividido em classes principais que são, por seu turno, novamente divididas. 
O que mais marca a CC, no entanto, são as categorias ou facetas por ele propostas: Personalidade, Matéria, Energia, Espaço e Tempo, expressas geralmente pela fórmula PMEST.

Conforme Vickery, citado por Grolier, pode-se identificar a categoria Personanalidade à idéia de substância aristotélica. Para Grolier, no entanto, em Personalidade são tratados os objetos de estudo de uma disciplina determinada, tal como eles servem comumente de base à divisão tradicional dessa disciplina ou como a CC considera como mais prática. Segundo seu ponto de vista, a personalidade não é, assim, considerada, como tendo um valor teórico, mas como constituindo uma simples etiqueta colocada sobre as características das coisas, de modo mais ou menos arbitrário, para constituir as divisões hierárquicas de primeiro nível numa classificação que procura exprimir diferentes pontos de vista, mas que admite como indispensável a existência de uma ordem fixa e imutável entre os seus elementos.

Segundo Grolier, as divisões sob Personalidade nas diversas classes principais da CC mostram que se trata apenas de uma racionalização a posteriori de um método absolutamente prático (GROLIER, 1962, p.49).

A categoria Energia trata geralmente de problemas e ações, diferentemente manifestadas conforme as classes de assunto onde ocorrem: por exemplo, em mecânica, diz respeito ao movimento, ao equilíbrio, à vibração; já em astronomia, cronologia, geodésia, astronomia 
esférica, física, teórica, cosmogonia. Em física, diz respeito a problemas, como por exemplo, radiação, propagação, dispersão etc.

A terceira categoria geral é Matéria, e diz respeito aos materiais de construção, constituição, como por exemplo, a matéria de que são feitas as esculturas, em Artes, ou os instrumentos, na Música, por exemplo.

As categorias Tempo e Espaço tratam, respectivamente, de divisões temporais e geográficas, tanto distribuídas pelas classes de assunto como fazendo parte de uma tabela em separado.

\section{- Depois da Colon Classification}

No relatório de Grolier, a CC é considerada o último sistema de classificação enciclopédica de certa importância internacional. Grolier relata, no entanto, a experiência de Gérard Cordonnier no intuito de fazer um novo esquema enciclopédico detalhado. A importância de Cordonnier, para o autor, se deve mais à contribuição na popularização de uma série de categorias, cujo detalhamento foi exposto na Conferência de Dorking, em 1959:

- Organismos e serviços

- Pessoas

- Indivíduos

- Corpos 
- Materiais diversos

- Ações diversas

- Conceitos intelectuais

- Formas documentárias

- Tempo

Grolier observa, no entanto, que o próprio Cordonnier, na conferência de Cleveland, propõe a criação de uma terminologia sintética para uma classificação polidimensional, podendo-se afirmar que pode estar subjacente a esta proposta uma revisão radical da série de categorias anteriormente proposta.

Grolier cita, também, entre outros, o trabalho relacionado ao estabelecimento de categorias, realizado pelo Classification Research Group (CRG) que, embora tivesse o intuito de elaborar uma classificação enciclopédica, acaba por produzir apenas sistemas especializados que adotam o método de análise por facetas de Ranganathan, mas não suas categorias fundamentais. As categorias propostas pelos vários integrantes do CRG variam conforme o domínio focalizado, sendo antes de tudo propostas de separações artificiais.

Para analisar as classificações e codificações documentárias especializadas, Grolier adota o agrupamento por países, examinando os instrumentos segundo a ordem geográfica adotada. Sem entrar em 
detalhes, podemos verificar que as propostas aí analisadas tendem a mostrar critérios pragmáticos, mais do que filosóficos ou outros à base da categorização. Como exemplos, podemos citar:

- categorizações baseadas na teoria dos reflexos condicionados (Tchakhotine, aluno de Pavlov): noções morfológicas, químicas, funcionais normais, funcionais patológicas etc;

- grupos de rubricas por combustíveis usados na soldagem: material, procedimentos, aplicações, produtos, problemas gerais (Dobrowolski, 1942-43);

- noções reunidas em classes e repartidas em grandes divisões para tratar dos estudos demográficos: meio físico, o homem, as comunidades humanas, acompanhadas de divisões comuns (Robert Desaubliaux, 1942-43);

- grupos gerais que denotam o processo cronológico de construção: concepção geral das obras, conhecimentos para o estabelecimento do projeto técnico da obra, técnica ou arte de construir, obras propriamente ditas.

Mais do que ênfase na categorização, alguns sistemas privilegiam as relações sintáticas entre os elementos - união e intersecção, tematização, subordinação, etc., - que ligam categorias de noções, como ciência, conhecimento científico ou similar; aspecto, organização, caracterização; indivíduo, elemento; seres e propriedades lógico-matemáticas; fatos e 
propriedades físico-químicas, etc. Outras propostas relacionam níveis crescentes ou decrescentes de abordagem de um assunto - por exemplo, em energia nuclear, escala corpuscular, nuclear, atômica e molecular, macroscópica.

Em destaque, Grolier coloca os trabalhos de Jean-Claude Gardin que, a partir da constatação de que 'os termos da linguagem natural correntemente empregados para a descrição fina dos objetos são muito vagos e pouco normalizados', propõe substituí-los por 'códigos compactos'. Tais códigos variam com o domínio abordado - por exemplo, para os instrumentos de metal da idade do bronze, as tabelas relacionam formas, modo de encaixe, dimensões, contorno dos corpos, ligações entre eles, nervuras e arestas, particularidades diversas etc. Métodos semelhantes foram aplicados, posteriormente, à análise conceitual de textos, como das 'tábuas' mesopotâmicas, Corão (ontologia, cronologia, meio natural, antropologia, filosofia/religião, ética), textos míticos etc. Sem entrar no tema da análise proposta, é preciso dizer que entre as categorias utilizadas pelo autor e por sua equipe, sistemas de relacionamentos constituíam uma espécie de gramática para fazer a representação mais adequada dos fatos e objetos observados. Grolier destaca o trabalho de Gardin pelas implicações que têm no domínio das pesquisas de recuperação da informação, uma vez que ele ultrapassa o estágio puramente bibliográfico das análises, para atender a um nível mais profundo do conteúdo conceitual dos documentos. Em destaque, o autor coloca as funções identificadas por Gardin: nível geral ou temático, 
onde há um assunto ou variável central ou principal e variáveis independentes (seres, espaço, tempo), e um segundo nível específico, onde se encontram unidades sintagmáticas, nas quais a função de um termo se define por relação a um só termo particular do contexto. Neste nível se dariam relações que correspondem a 'situações': relações predicativas, consecutivas ou de causalidade e finalidade, associativa e comparativa. Essas quatro relações formariam um sistema, que compreende relações intrínsecas, ou estáticas, e relações extrínsecas, ou dinâmicas, que unem os termos de análise reunidos nas categorias. Tais relações aconteceriam mais no nível abstrato, entre as categorias gerais, do que no nível de termos concretos e específicos do léxico. Como exemplo, ele cita $o$ fato de que as "estatísticas comparadas de esquizofrênicos entre [a população] rural e urbana, num país protestante", não implicaria uma relação consecutiva entre 'esquizofrenia', de um lado, e 'cidade ou campo', de outro, mas entre os termos genéricos como 'residência' e 'doença" (GARDIN citado por GROLIER, 1962, p.93).

A observação sobre os critérios pragmáticos que marcam as classificações documentárias feita por nós anteriormente, se estende às análises de Grolier sobre outros autores residentes na França ou em outros países. Isso se aplica ao modelo de Kaiser utilizado por Holmstrom, que propõe estabelecer relações entre categorias de ação, organismo, equipamento, nome geográfico, nome pessoal, qualidade, substância e título de uma publicação sobre a qual se faz a análise (GROLIER, 1962, p.97). Do mesmo modo, se aplica à proposta de Farradane, que distingue relações 
temporais, não temporais, fixas ou permanentes, distribuindo as categorias de co-existência, não precisada, precisada, para falar dos termos que são co-presentes, comparados, associados, equivalentes, pertencentes, passíveis de ser substituídos por, que denotam ação sobre, que põem em causa relações de dependência funcional.

Grolier destaca, também, as classificações do CRG, já citadas, mostrando as diferentes categorizações em função dos temas enfocados. Por exemplo, a classificação de Foskett sobre segurança e higiene do trabalho propõe categorias como Agentes físicos e fenômenos naturais; Substâncias; Locais, equipamentos, processos e operações; Organização do trabalho e estrutura Industrial; Fogo e explosões; Patologia; Fisiologia e psicologia, etc. Em Vickery, para a Classificação das Ciências do Solo, categorias como Tipos de solo, Estrutura, Constituintes, Propriedades, Processos naturais, Operações sobre o solo, Técnicas de Laboratório, Generalidades.

Os trabalhos dos Estados Unidos também não diferem muito dos anteriores, destacando sempre grupos de características relativas aos temas dos assuntos focalizados - processos e propriedades, atributos como, algumas vezes, a distinção entre relações analíticas e sintéticas, etc., como base para a observação do relacionamento entre as categorias de dados.

A relatar, o método de descritores de Calvin Mooers que não utiliza, de fato, uma categorização, mas organiza um dicionário de noções que 
respondem a objetivos particulares. Cada descritor representa uma idéia ou conceito, geralmente amplo e às vezes definido por uma nota de escopo. A cada documento corresponde uma lista de descritores visando caracterizar o documento. Uma lista de cabeçalhos de capítulo reagrupa os descritores.

Grolier também se refere aos trabalhos de J.W.Perry feitos para a Western Reserve University, mas pontua que a classificação feita por seu grupo não apresenta traços particularmente importantes, agrupando os assuntos em três partes: processos e propriedades, materiais, atributos comuns. Outra classificação feita por ele propõe classes gerais segundo o tipo de entidade ou conceito: máquinas, aparelhos, dispositivos, materiais, substâncias, atributos, características, conceitos abstratos, mas categorias de domínio geral: química, física, mecânica etc.

Perry, juntamente com Kent, produz também um método de análises codificadas, cuja importância diz respeito à indicação detalhada de relações entre os termos; relações para os materiais, para as propriedades, para os processos, para as condições e para papéis diversos. Esses 'indicadores', como denominam, se juntam a outros, que dizem respeito à pessoa ou entidade enquanto agentes, aos organismos e seus tipos, à situação dos organismos, organismos subordinados, clientes, fonte de informação, lugar indicado para a sociedade ou grupo de indivíduos, quantidade, tipo de artigo. 
Para o Patent Office, um dos trabalhos destacados por Grolier se refere à criação de uma metalíngua voltada à resolução de problemas de ambigüidade lingüística. Denominada Ruly English, tal metalíngua compreende seis categorias de elementos: raízes e qualificativos, sufixos modulantes, prefixos de quantificação, conceitos de inter-relações, nomes de interfixos, nomes de rubricas.

Quanto aos trabalhos de H.P.Luhn, Grolier ressalta a compilação de dicionários de noções bastante semelhante ao tesauro, sendo o autor considerado um dos responsáveis pela recuperação da idéia de Roget e seu uso na Documentação. Ainda nos EUA, Grolier cita o trabalho de Mortimer Taube e os unitermos, ou palavras típicas tiradas dos títulos ou dos textos, método de indexação em fichas 'por pontos de vista', de certo modo análogo aos descritores de Mooers, mas que peca em não mobilizar categorias.

Na União Soviética, do mesmo modo, as propostas se aproximam das européias, como por exemplo, a utilizada pela Academia de Ciências da URSS: processos e estados, objetos, propriedades, conceitos abstratos e outros termos, nomes próprios (GROLIER, 1962, p. 145).

Um capítulo especial do trabalho é reservado, por Grolier, à observação das categorias gerais e sua expressão nas relações entre as línguas naturais e os ensaios de línguas auxiliares internacionais. Grolier ressalta que essa diferenciação foi estimulada pelos estudos sobre tradução automática, sendo em certa medida, seu desenvolvimento. Ao estabelecer 
relações entre a estrutura formal da língua $e$ das linguagens documentárias, observa que as últimas se inspiram nas primeiras.

Depois de expor rapidamente diferentes teorias sobre a linguagem, Grolier se detém em observar tipos de categorias lingüísticas, se reportando a problemas discutidos por lingüistas em vários eventos de trabalho: como são definidas classes de palavras, categorias verbais, categoria de pessoa, sistemas de casos, negação, gradação, totalidade, indicação, derivação. De forma sumária, Grolier fala dos problemas semânticos (léxico e classificação ideológica), das relações entre linguagem, lógica, língua, pensamento e cultura, que derivam relações entre categorias 'fixadas pelas línguas e 'concepções do mundo'; da tipologia das línguas (classificação genealógica); da evolução da linguagem como mecanismo mais ou menos eficiente para a transmissão da informação, etc.

Essa breve exposição é seguida de uma análise das categorias e relações nas linguagens artificiais, citando-se, inclusive, os projetos de línguas para a 'intercomunicação' entre línguas de estrutura diversa, tal como o projeto de uma 'interlíngua'. Embora Grolier não se posicione claramente sobre a questão, sabe-se, hoje, que o projeto é criticado e abandonado em função da impossibilidade de sua realização. Pode-se afirmar que, de fato, as escolhas sempre esbarrariam nos diferentes modos de categorização do mundo e, conseqüentemente, da informação.

Em linhas muito gerais, o texto acima procura resumir as características principais do trabalho de Grolier. Infelizmente, o projeto não teve 
continuidade, inexistindo, pelo que pudemos verificar em levantamento bibliográfico, outro trabalho no mesmo sentido analisando os instrumentos produzidos depois da década de 60 . O relatório elaborado por Grolier nos leva a concluir, no entanto, que a sustentação das categorias nos instrumentos documentários analisados está na sua utilidade prática, sendo, portanto, fortemente pragmática, característica enfatizada nos trabalhos posteriores das décadas de 60 a 90.

\subsection{A categorização aplicada na CI SOB A Ótica das InVEstigaçōes FILOSÓFICAS}

Após realizar uma retrospectiva sobre o tema da classificação e categorização a partir de autores clássicos, cujo pensamento remete geralmente, ao menos de modo implícito, às formas tradicionais de categorização fundadas em Aristóteles e Kant, relataremos, neste capítulo, a experiência de Blair que tem sua origem na proposta de Wittgenstein.

Para Blair, a natureza dos processos de indexação e busca da informação são temas primordiais, que podem ser trabalhados a partir da proposta da filosofia da linguagem, na perspectiva das "Investigações Filosóficas" de Ludwig Wittgenstein (1889-1951). 
A proposta do autor parte da avaliação dos processos de indexação e busca da informação frente à proliferação de coleções de documentos eletrônicos e sua ubiqüidade na web e a vasta disponibilidade dos motores e as ferramentas de busca (BLAIR, 2003).

A recuperação da informação, para ele, é um processo fundamentalmente lingüístico, cujo maior obstáculo é a descrição do conteúdo, seja qual for o suporte de informação: livro, documento, imagem, áudio-visual, espécime científico, projeto de engenharia ou outros (BLAIR, 2003, p.4). A noção de significado é, para ele, um dos mais importantes componentes do processo de recuperação da informação, noção essa enfrentada de forma particular na visão de Wittgenstein. Na visão de Blair, o diferencial é a proposta de aprimoramento dos processos de recuperação relacionando a compreensão da linguagem e a cognição, ou seja, na perspectiva de que a linguagem é intrínseca ao modo como compreendemos as coisas em geral, e, conseqüentemente, ao modo como representamos a informação que resulta dessa compreensão (BLAIR, 2006).

\subsubsection{A contribuição da filosofia da linguagem}

Para Blair, desde a época remota de Aristóteles, nenhum outro filósofo teve tanta importância na filosofia da linguagem quanto Ludwig 
Wittgenstein (1889-1951). Nas "Investigações filosóficas"12, Wittgenstein pontua a volta da importância da lingüística, como resposta aos filósofos que supunham estudar "idéias", mas que no seu entender estavam, na verdade, estudando "descrições de idéias". Dito de outra forma, estudavam não exatamente aquilo que eles estavam pensando, mas o que eles diziam que pensavam. Corroborando ao que já se apontou anteriormente, Blair mostra que Wittgenstein argumentou que muitos dos problemas filosóficos não passavam de conseqüências de mau uso da linguagem, o que o fez definir a filosofia como "uma batalha contra o encantamento de nossa inteligência mediante a linguagem" (BLAIR, 2003, p.9 $)^{13}$. A importância que Wittgenstein atribui à filosofia demonstra que ele não considerava a filosofia somente uma coleção de enigmas, mas sim um guia para a vida:

(...) para que estudar filosofia se tudo o que ela faz é possibilitar-lhe falar sobre plausibilidades de questões confusas de lógica, etc., se isso não melhora as questões importantes da vida diária? (WITTGENSTEIN apud BLAIR, 2003, p.10).

Retomaremos aqui o pensamento de Wittgenstein através de Blair correndo o risco de nos repetirmos. Consideramos, porém, que dada a ênfase que o autor confere ao trabalho do filósofo, essa retomada é

\footnotetext{
12 WITTGENSTEIN, L. Philosophical investigations. 3.ed. Oxford/UK: Blackwell Publishers, 2001. (Translated by G.E.M. Anscombe, published 1953). Referência citada em BLAIR, D. (2006).

${ }^{13}$ As referências ao texto de Blair constituem tradução livre da autora.
} 
importante para nos auxiliar a verificar as relações entre suas contribuições e as questões da representação em Ciência da Informação.

Blair destaca uma característica muito particular do trabalho de Wittgenstein que inaugura uma nova perspectiva no campo da ciência, quando são deixadas de lado as preocupações com a delimitação nítida dos campos de conhecimento. De fato, Wittgenstein parecia não ter a preocupação (ou a intenção) de separar seus trabalhos por temas sempre recorrentes, como por exemplo, matemática, lógica e psicologia. A maior lição dos seus escritos talvez tenha sido exatamente essa característica, justamente observada por John Searle:

(...) quando você se depara com os últimos trabalhos dele [Wittgenstein] e os lê, é como se recebesse um kit de um modelo de aeroplano sem nenhuma instrução de como montá-lo, o que considera ser extremamente frustrante. (...) Porque ele escrevia assim?... Eu honestamente penso que ele queria dizer alguma coisa nova e diferente, e ele sempre tinha a sensação de que não havia dito o que realmente queria dizer, que continuava tentando achar um modo adequado para se expressar. $\mathrm{E}$ na sua mente, ele nunca conseguiu realmente. Finalmente, penso que é necessário dizer aos leitores de língua inglesa que esse estilo, embora pareça estranho aos olhos dos leitores Anglo-Americanos, não é tão incomum na Alemanha. Há uma tradição na filosofia alemã de escrever aforisticamente. Você encontra em Nietzche, Schopenhauer e Lichtenberg, para mencionar somente alguns (SEARLE apud BLAIR, 2006, p.29).

De modo similar é enfocada a questão do significado, conforme trecho destacado por Blair:

Quando penso em linguagem, não há "significados" rondando minha mente em adição às expressões verbais: a 
linguagem é por si mesma o veículo do pensamento (WITTGENSTEIN apud BLAIR, 2006, p.12).

Sob tal concepção, o pensamento não utiliza a linguagem como um meio, mas sim como significado do pensamento. Não como seu produto ou como a expressão de algo que "temos em mente" (WITTGENSTEIN apud BLAIR, 2006, p.12).

Se a linguagem é considerada como veículo do pensamento, há conseqüências a serem examinadas, observa Wittgenstein. Primeiramente, Wittgenstein avalia que temos palavras e expressões disponíveis em nosso vocabulário, estabelecendo um certo limite não somente para o que dizemos, sobretudo para o que pensamos. Assim como um pintor tem seu estilo, bem como uma escala e matizes próprios, cada um de nós possui um vocabulário, estilo e expressões verbais peculiares. Mesmo que utilizemos palavras comuns, há um arranjo criativo que se diferencia de todos os demais, é único. Há as metáforas, determinadas pelo uso de expressões familiares para exprimir novas idéias. Isso explica porque nossos pensamentos são tão vinculados à nossa linguagem (WITTGENSTEIN apud BLAIR, 2006, p.12).

Para Blair, essa "Revolução Copernicana" estimulada pelas investigações de Wittgenstein tem implicações fundamentais para o processo de recuperação da informação. Blair avalia que esse processo é freqüentemente visto como aquele no qual o usuário tem algo "em mente" 
- uma necessidade de informação - que é traduzida para uma verdadeira questão de informação, assim como as pessoas têm "idéias" que precisam ser expressas em linguagem natural. Grosso modo, a linguagem de recuperação (output) disponível limita de maneira muito grande a resposta às nossas necessidades de informação, já que a linguagem de indexação (input) não representa exatamente aquilo que necessitamos. A linguagem de recuperação não só limita a articulação daquilo que necessitamos como também reprime o próprio processo de pensamento das nossas reais necessidades de informação. Presume-se que moldamos os sistemas de recuperação da informação para servir às nossas necessidades de informação, mas se Wittgenstein está certo em suas afirmações, ocorre exatamente o oposto: os sistemas de recuperação da informação é que nos impõe como pensar dentro de seus critérios. Se essa afirmação é verdadeira, então talvez seja extremamente difícil projetar sistemas de recuperação da informação diferentes ou mesmo aperfeiçoar os já existentes, porque estamos viciados nos modelos atualmente disponíveis (BLAIR, 2003).

A questão da representação da informação, incluindo-se ai entidades tangíveis ou intangíveis, ou, como Blair prefere "palavras que designam objetos", sempre foi polêmica. Wittgenstein considera que o significado de uma palavra é definido com o seu uso na linguagem (WITTGENSTEIN apud BLAIR, 2003, p.15). Blair compreende que o significado está além da simples referência entre "nome" e "objeto", e suspeita que deve haver algo mais além da simples referência. 
Em suas pesquisas para aprimorar o processo de recuperação da informação, Blair referencia também alguns notáveis pensadores citados por Wittgenstein, dentre eles, St. Agostinho, cujo modelo de linguagem reforça a dicotomia básica entre designação e significado, porém, deixa aos filósofos sucessores a tarefa de resgatá-la. A dicotomia sugerida por St. Agostinho compreende um modelo simples, mas com características sutis que demonstram certa proximidade com a teoria de Wittgenstein, segundo $\mathrm{o}$ autor. Esse modelo comporta o entendimento de que o "significado" pode existir independente de seus correspondentes verbais (designação) e exemplifica tal possibilidade da seguinte forma: pensamos numa designação que tem um significado da mesma maneira como pensamos em pessoas que têm pais biológicos. Uma criança pode desconhecer quem são seus pais, mas ao mesmo tempo, a sua existência é indiscutível. Da mesma forma, Wittgenstein acreditava na dicotomia entre significado e designação, porém, acrescida da contribuição de John Locke que foi capaz de articular uma teoria alternativa do significado, mas sem resvalar nas falhas de St. Agostinho. Para Locke, "designações em seus significados puros ou imediatos servem para nada, a não ser que sejam empregadas com as idéias" (LOCKE apud BLAIR, 2003, p.19). O elo entre o "significado e a designação" com a "idéia" resolve o problema de designações que não remetem a objetos, assim como o fazem algumas teorias que assumem que aquilo que temos "em mente" é o significado das designações, não a designação em si (BLAIR, 2003). No entanto, há críticas que apontam problemas fatais à teoria filosófica de Locke sobre o 
significado. Se entendermos que o mundo possui um significado individual, como será possível comunicá-lo a alguém ou até mesmo compreender o significado de mundo de outro, que por sua vez também é uma compreensão privada? Os seres humanos se comunicam, trocam idéias, frases entre si. A pergunta que não quer calar é: essa comunicação é realmente uma comunicação de idéias? Se houver algum truncamento nessa comunicação, qual é a fonte de erro? Nesse caso, a idéia foi elaborada corretamente, mas comunicada de forma incorreta, ou a idéia foi mal elaborada na sua origem? Segundo Blair, não há como responder a essas questões. Há a certeza de que para nos expressarmos são necessários critérios claros de precisão, algo que Blair indica que a pura teoria filosófica do significado não pode oferecer. No entendimento de Wittgenstein, o que pode garantir critérios que assegurem a compreensão do significado da palavra/designação não é a idéia correta, mas sim seu uso adequado no discurso e escrita corrente (WITTGENSTEIN apud BLAIR, 2003).

Em Wittgenstein, segundo Blair, cada palavra tem o seu significado de acordo com seu uso. Mesmo que sejamos capazes de identificar uma designação com segurança, certamente essa mesma designação terá aplicações em diferentes circunstâncias, segundo os "jogos de linguagem". Para explicá-lo, Blair destaca a comparação feita por Wittgenstein sobre o jogo de baseball, muito embora, assim como em outro qualquer, há uma possibilidade enorme de ocorrer eventos que não estavam anteriormente previstos, demonstrando que mesmo com o estabelecimento de regras, 
não há como prever todas as ações possíveis num jogo. Os "jogos de linguagem" retratam como reconciliar a necessidade na linguagem de uma estrutura predicável com a necessidade simultânea da flexibilidade do uso. A estruturação da língua é necessária, e é, sobretudo, dinâmica e flexível, aspectos esses que devem ser respeitados (BLAIR, 2006, p.80).

\subsubsection{A categorização em Blair}

A categorização é entendida por Blair como um dos aspectos mais importantes da linguagem e, por inferência, do pensamento. A idéia central de categorização, segundo o autor, é a possibilidade de encontrar características semelhantes nas coisas individuais, mesmo que em alguns aspectos elas sejam diferentes. Muitas expressões contêm referências explícitas a categorias: mesas, cadeiras, carros, pessoas, árvores, sentimentos, cores, etc. De fato, é difícil encontrar uma expressão que não contenha uma referência a, no mínimo, uma categoria. Em verdade, as categorias são consideradas como a base da linguagem. Ellis, citado por Blair, comparou a categorização em uma de suas obras como o "coração da linguagem", e acrescentou:

Categorização, e não a sintaxe, é o aspecto básico da linguagem, e é um processo fundamental que deve ser compreendido corretamente (...) e a categorização, não a comunicação, é a função mais importante da linguagem, aquela que antecede todas as demais (...) Toda linguagem é um sistema particular de categorização (...) (ELLIS citado por BLAIR, 2006, p.90). 
Em tese, sem a categorização, a linguagem como a conhecemos não seria possível. Se todas as ocorrências fossem itens únicos, completamente desagregadas de categorias, então novas expressões teriam de ser elaboradas a cada vez que surgisse um novo objeto ou evento, e assim não haveria nenhum significado que pudéssemos utilizar em instâncias subseqüentes. Seria como se, em nossas atividades diárias considerássemos cada objeto, situação ou evento como sendo únicos não existindo categorias para coisas tão triviais como "comida", "perigo", "amigo", "água", etc. Como conseqüência, seríamos não só incapazes de lidar com qualquer um desses conceitos, como também não poderíamos estabelecer sentido sobre qualquer um deles que possibilitasse sua aplicação no futuro ou no passado (BLAIR, 2006). Não haveria referências ou relações de nenhuma espécie, mas sim um mundo totalmente desconexo, no qual não pudéssemos nem ao menos reconhecer o caos.

Todavia, a categorização é uma forma de simplificação que provê um sistema de referência básico no qual coisas que são fundamentalmente diferentes são tratadas como se fossem semelhantes (BLAIR, 2006). Isso significa, pelo menos em parte, que as suas diferenças não interferem em seu uso. Se tivermos dois cães pastores, embora cada um seja único, podemos tratá-los como membros da mesma categoria. Isso é feito reunindo critérios para os membros da classe para tratar alguns aspectos tão importantes, tais como a cor ou manchas no pelo, o tamanho e formato das orelhas de cada um deles, e outros irrelevantes, tais como o peso exato, o som do latido ou a data de nascimento, respectivamente. É 
igualmente verdadeiro afirmar que membros de uma categoria possam também pertencer à outra categoria: dois cães pastores podem compor a categoria "meus cães", ou somente um pode estar na categoria "show de cães" enquanto o outro não, assim como ambos podem pertencer à categoria de "cães de guarda", etc. (ELLIS citado por BLAIR, 2006, p.92).

No entanto, a linguagem não é somente um modo de simplificação. As categorias que estão explicitas na linguagem determinam como "experienciamos" a realidade. Certamente, elas determinam como consideramos que a realidade deve ser. Blair se reporta à relação entre 'linguagem' e 'realidade' tal como foi apresentada pelo filósofo John Searle que afirmou que "nosso conceito de realidade está intrinsecamente relacionado às nossas categorias lingüísticas" (SEARLE apud BLAIR, 2006, p.93).

Blair reconhece que falar em categorização implica em abordar temas polêmicos, embora nem sempre inéditos. Blair resgata algumas idéias predecessoras sobre a percepção do mundo, tema que compreende o processo cognitivo e que, por sua vez, comporta o ato de categorizar, segundo citação de Even Goethe:

A coisa mais importante é compreender que tudo o que é fatual já está teorizado.

(...) então podemos afirmar que toda vez que olhamos atentamente para o mundo já estamos teorizando (ELLIS apud BLAIR, 2006, p.93). 
Contudo, Blair assegura que, embora seja ponto pacífico o fato da categorização ser considerada um aspecto essencial da linguagem, há um grande número de teorias concorrentes sobre como opera a categorização. Como os autores clássicos da área de Biblioteconomia o fizeram, Blair também propõe uma sistematização das formas de categorização através do tempo.

Na filosofia, o assunto "categorização" se reporta tradicionalmente às relações entre "universais e particulares". É possível compreender essa relação com as seguintes perguntas: Como podemos chegar a conceitos universais se só conseguimos observar unidades particulares? Como ocorre essa generalização de conceitos? Filosoficamente, a questão é encaminhada em torno de três pontos de vista: realismo, conceitualismo e nominalismo.

O principal representante do realismo foi Platão (427-347 d.C.) que acreditava no verdadeiro conhecimento como imutável, estático e, portanto, impossível de ser modificado ou considerado como fonte de conhecimento pelas nossas experiências rotineiras. O conhecimento para Platão originava-se de um "campo de idéias", dimensão completamente à parte do cotidiano e de onde extrairíamos todos os conceitos gerais de coisas como "mesas" e "cadeiras". Os conceitos de entidades não materiais, tais como "maravilhoso" e "bom" e relações como "maior que" ou "igual a" também seriam derivados da mesma dimensão (BLAIR, 2006, p.95). 
Aristóteles fez algumas ressalvas ao "campo das idéias" imaginado por Platão argumentando que essa realidade à parte causava mais problemas do que soluções. Assim, Aristóteles propôs uma "tabela" geral que abrangesse todas as entidades na qual seriam tratadas como pertencentes à mesma categoria. De fato, o realismo platônico e aristotélico persistiu por vários séculos até que essas teorias começaram a apresentar problemas em sua versão estrita do realismo. Como observado por Ellis, há sempre alguns aspectos de membros de determinada categoria que podem diferir dos aspectos dos demais. Esses membros podem fazer parte de uma determinada categoria bem como compor uma outra categoria simultaneamente. O fator determinante nesse caso varia de acordo com a contingência, o contexto ou a circunstância. Uma caneca de sopa num supermercado tem uma conotação totalmente diferente de uma caneca exposta no Instituto de Arte de Chicago (BLAIR, 2006, p.97). Tal abordagem nos leva a considerar que as similaridades ou diferenças entre coisas não são decisivas para a definição ou não de seus membros em categorias diferentes. Essa foi uma das principais críticas do nominalismo ao realismo.

William of Ockham (1280-1347) é indicado por Blair como um dos maiores precursores da corrente nominalista, e também uma das muitas vítimas da Peste Negra, a mesma que causou o desaparecimento de grande parte da inteligentsia medieval. Talvez esse fato explique o obscurantismo intelectual que assolou a era medieval do Norte da Europa. Ockham questionava como seria possível encontrar interação entre entidades 
individuais. Em sua concepção, Ockham considerava todo conhecimento como sendo proveniente das entidades particulares ou individuais de nossa experiência, abstraindo as características comuns dos objetos de nossa experiência formando os conceitos universais.

Quanto ao "conceitualismo", proposto por John Locke (1632-1704) que foi classificado por alguns autores, tais como Russell e Windelbald, como um autêntico nominalista, Blair pondera tratar-se de uma teoria bastante próxima ao nominalismo. Enquanto o nominalismo rejeita o dualismo do realismo (particulares e universais), o conceitualismo de Locke traz à tona outra forma de dualismo, considerando que uma palavra é geral ou significativa somente até que um conceito geral seja associado a ela. Embora a versão de Locke (conceitualismo) da teoria dos universais seja mais complicada que a do nominalismo tradicional, para Blair, pelo menos ele admite em sua versão que os conceitos gerais podem mudar ao longo do tempo.

A polêmica causada pela questão dos conceitos universais e particulares é tão fundamental para a elaboração das teorias da categorização que essa questão tem derrubado muitas delas. Locke sugeriu que não separemos conceitos particulares dos universais, mas somente trabalhemos com conceitos particulares. Para o autor, podemos empregar um conceito particular de uma forma geral, de acordo com as suas características, critérios, conveniência e utilidade. A contribuição de Locke sobre o debate de conceitos universais e particulares está exatamente no reconhecimento 
de que qualquer teoria da categorização deve possibilitar a flexibilidade das categorias que são por ele consideradas dinâmicas, e cujos membros são definidos por "critérios de conveniência e utilidade" (BLAIR, 2006, p.101). Nesse quesito, a abordagem de Locke chega a ser moderna.

Embora essa discussão pautada nas teorias realista e nominalista gerada sobre a questão dos conceitos universais e particulares possa trazer alguns esclarecimentos que são reconhecidos por Wittgenstein, a sua interpretação tende a rejeitá-las em seus formatos integrais. Blair destaca que, para tanto, Wittgenstein argumenta que devemos nos focar nos exemplos específicos de como termos particulares, frases ou sentenças são empregadas (WITTGENSTEIN apud BLAIR, 2006, p.101). Em outras palavras, qualquer teoria que não reconheça a relação existente entre significado e uso de conceitos seria igualmente recusada pelo autor (WITTGENSTEIN apud BLAIR, 2006, p.102).

Por sua vez, o realismo aristotélico também foi alvo de rejeição por Wittgenstein. Como dedução, Wittgenstein exemplifica que se pensarmos nos tipos de jogos, nem sempre encontramos um conceito comum a todos eles. Ao pensarmos, por exemplo, no jogo de xadrez e na "amarelinha", concluímos que ambos têm tão pouco em comum que se torna curioso identificá-los como "jogos". Esse é um vício prejudicial, segundo Wittgenstein, que ocorre em análises filosóficas, impedindo que a se chegue a um resultado satisfatório. 
De acordo com Blair, a introdução, por Wittgenstein, das "semelhanças de família" é importante para a compreensão dos "jogos", uma vez que é ideal para caracterizar algumas (e não necessariamente todas as) particularidades entre membros de família: corpo, feições, cor dos olhos, porte, temperamento, etc. As "semelhanças de família", no entendimento de Wittgenstein, justificam a descontinuidade de características comuns em todos os membros de uma determinada categoria, mas, por outro lado, sobrepõem e conectam essas similaridades ao longo da categoria. Inicialmente, a teoria dominante de categoria era a de Aristóteles, especialmente nas ciências biológicas, e pressupunha que os membros de uma mesma categoria deveriam ter propriedades em comum. $\mathrm{Na}$ perspectiva aristotélica de categoria, "cães" eram "cães" por que apresentavam características comuns a todos os membros, e essas propriedades na sua maioria, eram diferentes das características dos demais mamíferos. Embora esse método de análise tenha uma longa tradição, sabe-se que a sua aplicação generalizada ocorreu em função da imitação de métodos de análise científica de sucesso, tal como a análise química (BLAIR, 2006, p.105). A metodologia empregada na análise química opera com um procedimento de redução, decompondo as substâncias ou coisas em elementos. E Wittgenstein mais uma vez contesta o método de redução aplicado à análise filosófica, argüindo:

Quando filósofos usam uma palavra: "conhecimento", "ser", "objeto", "eu", "proposição", "nome" - e tentam extrair a essência da entidade/objeto, deve-se sempre perguntar: a palavra está realmente sendo empregada na forma de jogos de linguagem, com seu significado usual? (...) O que 
fazemos é resgatar as palavras de seu sentido metafísico para seu uso corriqueiro (BLAIR apud WITTGENSTEIN, 2006, p.107).

De outro modo, estaríamos retirando de cada palavra seu significado comum àquelas atividades as quais sempre as utilizamos. Senão, vejamos pelo exemplo de Wittgenstein no qual usamos a palavra "vassoura" atrelada ao contexto "limpeza" ou "faxina". Se nos referimos à "vassoura", não faria sentido dizer que "o cabo e a escova" compõe uma vassoura, já que uma vassoura é composta dessas partes. Se utilizarmos a palavra "vassoura" em um contexto usual, não há motivos para reduzir ou decompor suas partes. A não ser que se trate de um outro contexto, como uma fábrica de vassouras, onde seja usual interrogar a alguém que trabalhe lá "você juntou corretamente o cabo à escova?" (BLAIR, 2006, p.106).

A inclusão da noção "formas de vida" por Wittgenstein reforça a idéia de que os jogos de linguagem não são constituídos ou regulados por regras explícitas, não podem ser definidos ou explicados da mesma forma que o jogo de xadrez ou a matemática (BLAIR, 2006, p.132). "Formas de vida" são demonstradas, não podem ser inteiramente definidas ou descritas, são dinâmicas, seu grau de mudança varia de acordo com as atividades que elas representam (BLAIR, 2006, p.127). Se avaliarmos os princípios da atividade "andar a cavalo" como meio de locomoção, encontraremos tantas semelhanças quanto "andar de charrete" ou mesmo "dirigir um 
carro", categoria essa que apresenta muitas variações (alguns carros possuem quatro marchas, outros cinco e outros ainda possuem transmissão automática). Observa-se que a atividade "locomoção" continua existindo em quaisquer das modalidades acima descritas.

Assim, as noções de "jogos de linguagem" e de "formas de vida" estão relacionadas, pois, de acordo com Wittgenstein:

(...) não partimos de certas palavras, mas sim de determinadas ocasiões ou atividades. (...) o termo "jogos de linguagem" é compreendido a partir do uso da linguagem como parte de uma atividade, ou de uma forma de vida (WITTGENSTEIN apud BLAIR, 2006, p.129).

A partir da linguagem e "formas de vida" é possível definir uma estrutura do uso da linguagem e estabelecer a participação em atividades humanas regulares, respectivamente, porém, sem ter que recorrer a uma lista de regras, consciente ou inconscientemente. Ao contrário, linguagem e formas de vida dão suporte a um tipo de estrutura natural que nos possibilita agir ou falar de determinadas maneiras e não de outras.

Ao término da breve síntese do trabalho de Blair, salientamos uma observação feita por Lara (1999) sobre seu trabalho. A autora aponta que o discurso de Blair é particular no interior da literatura documentária, diferindo da maior parte dele ao questionar os parâmetros fundantes da representação (e poderíamos acrescentar, categorização) utilizados assentados na crença nas essências e na possibilidade da descoberta de categorias gerais de análise. Pontua a autora, porém, que 
Essa proposta (...) ignora as contribuições geradas no interior de outros paradigmas e corre o risco de utilizar apenas o senso comum como parâmetro. As Atividades (Formas de Vida) não são mais do que as terminologias de domínio do saber ou de atividades vistas sob o ângulo da Socioterminologia, cuja ênfase (...) está centrada no uso. A grande diferença está em propor os Jogos de LInguagem na ausência de um reconhecimento mais explícito das características comunicacionais da representação da informação" (LARA, 1999, p.59).

\subsubsection{A categorização em lyer}

Hemalata Iyer é, atualmente, professora associada do Department of Information Studies da University Albana e autora de vários estudos em Ciência da informação. Sua visão da categorização, de certo modo, combina parâmetros clássicos e contemporâneos. Sua inclusão neste trabalho se deve ao fato de ela ser uma das únicas que, contemporaneamente, fala explicitamente em categorização. Na sua ótica, a organização da informação implica no estabelecimento de uma estrutura e a estruturação do conhecimento é uma forma de legitimar os domínios de conhecimento para facilitar a comunicação, o ensino, e a aprendizagem ${ }^{14}$ (IYER, 1995).

Iyer considera como função dos especialistas em informação a intermediação entre conhecimento registrado e os seus usuários, bem como indica a função dos professores, cujo papel, segundo a autora, é interpretar uma área de conhecimento para os estudantes. Para cumprir

\footnotetext{
${ }^{14}$ Neste trabalho realizamos uma tradução livre do texto de Iyer (1995).
} 
essa função, os bibliotecários organizam o conhecimento para recuperação. Organizar, segundo Iyer, requer uma estrutura, e estruturar o conhecimento é uma forma de legitimar o domínio com o empenho dos bibliotecários, assim como dos filósofos. A autora enfatiza que o conhecimento por si só não possui estrutura, que é imposta por filósofos para facilitar a comunicação, o ensino, e a aprendizagem, a partir da divisão do conhecimento em disciplinas como Química, Matemática, Sociologia, Medicina etc. Bibliotecários usam a divisão do conhecimento em disciplinas como base para a organização de conhecimento registrado em bibliotecas (IYER, 1995). Ao aproximar estrutura à distribuição em disciplinas, poder-se-ia inferir que a autora compartilha do pensamento tradicional sobre categorização. No entanto, sua proposta é ligeiramente diferente, conforme se pode verificar a seguir. A partir do pressuposto de que as disciplinas são sistemas sociais, assim como os sistemas do conhecimento, constata-se que esses são sempre influenciados pelo clima cultural e intelectual de seus respectivos tempos (HECKHAUSEN citado por IYER, 1995, p.24). Do mesmo modo, as influências históricas dissociadas das disciplinas podem afetar o seu desenvolvimento.

Iyer (1995) afirma que uma disciplina pode ascender e decair em importância através dos ciclos históricos. Como argumento, a autora cita o crescimento da ciência no século XVIII que pode ter tido conseqüências devastadoras para a teologia e modificado a face da filosofia. Inversamente, há evidências de que os experimentos de Charles Babbage 
e outros têm tido uma imensa importância prática para a ciência da computação.

Como se nota, Iyer (1995) considera que a aplicação original das categorias usada na documentação foi voltada à classificação de disciplinas e não a conceitos. Na atividade documentária, segundo a autora, um conceito não possui definição fixa podendo movimentar-se por diversas disciplinas. A adoção de limites sólidos entre as categorias, a formação dos conceitos baseada na suposição de que o mundo real é estruturado em grupos hierárquicos que compartilham propriedades inerentes, também podem ser apontadas como problemas para a aplicação da classificação aristotélica como princípio de categorização nos sistemas de informação modernos. Todavia, admite que a função das categorias é orientar a formação criteriosa de agrupamentos e fornecer critérios para a segmentação e agrupamentos úteis a determinados objetivos (IYER, 1995).

Iyer parte do triângulo conceitual introduzido por Dahlberg para representar a formação de conceitos, assim como demonstrado na Figura 3:

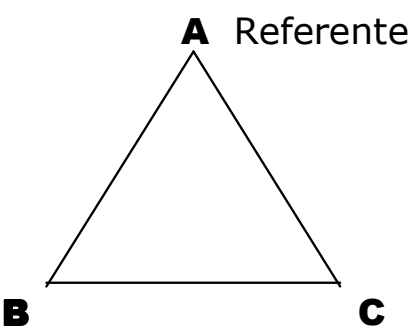

Características

Expressão verbal

Figura 3 - Triângulo conceitual de Dahlberg (Fonte: IYER, 1995, p.40). 
Da composição dos três elementos - referente, características e expressão verbal - é derivada a "unidade de conhecimento". Para a autora, as categorias são "unidades de conhecimento" que compreendem afirmações necessárias e verificáveis sobre um referente, representada por uma designação (IYER, 1995, p.12), mesma afirmação de Dahlberg, o que pode ser interpretado dentro do pensamento da ciência moderna.

Iyer afirma que os conceitos nos permitem obter mais informação do que simplesmente observar a coisa em si ou mesmo ouvir a sua designação (palavra). Assim, quando se ouve o termo "computador portátil" ou "laptop", imediatamente sabemos que se trata de algo que possui as propriedades de ser portátil, ter um monitor e um teclado. Além do mais, podemos inferir dessa relação o conceito geral "computador", equipamento utilizado para processar a memória da mesma maneira, contudo, de maneira reduzida, já que a sua capacidade de processamento deve ser menor. Essa é a base dos sistemas hierárquicos em sistemas especializados, como conhecido na área da computação.

Na concepção dada por Iyer, as categorias concedem estabilidade e ordem ao mundo que percebemos, segmentando-o, possibilitando agrupamentos de objetos de formas utilizáveis. Nesse sentido, torna-se impossível pensar sem formar categorias. Todo objeto ou idéia que encontramos é, automaticamente, comparado com outras coisas que conhecemos, numa tentativa para compreendê-lo de modo que nos seja útil. Um "computador portátil" ou "laptop" pode, simultaneamente, ser agrupado como uma 
pequena caixa, um processador de palavras, um dispositivo de comunicação, ou um brinquedo, dependendo da abordagem que imprimimos a esse objeto e do uso que faremos dele naquele momento. Iyer afirma que a categorização é primariamente baseada na similaridade, na equivalência, enquanto que os conceitos dentro de uma determinada categoria resultam num relacionamento mútuo. As propriedades comuns usadas para relacionar conceitos numa categoria podem ser empregadas como referência, isto é, características físicas ou atributos, desenvolvimento ou funcionamento da coisa em questão. Às vezes, as propriedades comuns de um conceito, ou propriedades correlacionadas são usadas para ajudar a definir uma categoria. Por exemplo, se um animal tem um bico adunco e penas, provavelmente seja encaixado na categoria de "pássaros", se tiver nadadeiras e guelras, provavelmente pensaremos na categoria "peixe" (IYER, 1995).

Iyer reconhece que o modo acima de categorizar segue a abordagem clássica, atitude em cuja base estão estruturas do conhecimento relativamente universais e estáveis.

Do mesmo modo que outros autores, Iyer também reconhece que, além da Biblioteconomia e da CI, outros campos do conhecimento também possuem investigações importantes sobre a questão da categorização. Para tanto, Iyer cita as diferentes abordagens feitas ao longo do tempo por antropólogos, psicólogos, filósofos e lingüistas, procurando reunir suas contribuições sob vertentes. 
A autora argumenta que o paradigma clássico de categorias tem origem na teoria aristotélica que é compreendido como o estudo de categorias "naturais", grupamentos que parecem ser comuns por todo ser humano, tais como móveis e animais. Segundo tal concepção, as categorias são isentas de interpretações resultantes de diferentes padrões sócioculturais. A abordagem clássica de categorias deduz que categorias "naturais" parecem espelhar especialmente o desenvolvimento biológico, tais como agrupamentos de espécies, gênero e família que seriam rapidamente óbvios a qualquer observador.

Iyer reconhece, também, a teoria da psicóloga Eleanor Rosch e sua equipe na década de 70, cujos estudos recentes em psicologia resultaram no desenvolvimento de novas bases para a categorização a partir da proposta do nível básico de categorias e dos protótipos. A característica fundamental da proposta é a rede de propriedades inter-relacionadas e a perspectiva de verificar que alguns exemplares definem melhor a categoria do que outros, numa clara conformação de uma estrutura graduada e de limites tênues entre os membros da classe e das categorias. Iyer ressalta também os resultados da abordagem de Wittgenstein, destacando a importância de reconhecer que as categorias são formadas baseadas na semelhança de família, mais do que por definições (similaridades parciais). No entendimento de Iyer (1995), há muitos outros conceitos que se diferenciam do paradigma clássico. Eles são conformados como uma rede de propriedades que conectam conceitos na maioria das categorias, em vez de um simples conjunto de 
propriedades definidas e disjuntivas. Dessa forma, alguns membros podem ser melhores exemplos que outros de uma categoria, assim como "truta" é um exemplo melhor da categoria "peixe" do que o "mascarado". Uma rosa e um dente-de-leão podem ser considerados igualmente bons exemplos de "flor", mas poderiam as flores minúsculas da grama serem consideradas como membros da mesma categoria? A idéia central do paradigma de estrutura graduada é a de que objetos dentro de uma categoria podem ser arranjados do melhor ao pior exemplo típico, cujos limites entre as categorias são indistintos. $\mathrm{Na}$ última década pesquisadores tais como Barsalou e Rosch provaram a existência de estrutura geaduada nas categorias por meio de vários experimentos. Tipicamente, assuntos são arranjados em categorias de acordo com sua utilidade. Nesse sentido, Iyer (1995) pondera que a definição de categorias e a classificação de seus membros depende muito de quem elabora a classificação (ver Figura 4).

Tal pressuposto confere com a noção de que as categorias são definidas de acordo com os critérios que atendem a necessidadades instituídas pela comunidade que faz uso de da informação. O fato comprova que o ambiente, a cultura, o conhecimento de quem realiza a classificação interfere no ato de incluir tomate na categoria "vegetais" ou na categoria "frutas".

Visto que a categorização é um processo efetivado por pessoas, Iyer (1995) afirma que as propriedades inerentes aos objetos não são os 
únicos determinantes do processo. Aspectos ambientais, comportamentais e culturais também contribuem para a efetivação da categorização.

\begin{tabular}{|l|l|l|l|}
\hline \multicolumn{1}{|c|}{ Flores } & Contos de fada & \multicolumn{1}{|c|}{$\begin{array}{c}\text { Transporte } \\
\text { mecanizado }\end{array}$} \\
\hline Mais típicos & Rosa & Cinderella & Carro \\
\hline Outros típicos & $\begin{array}{l}\text { Tulipa } \\
\text { Margarida } \\
\text { Narciso silvestre }\end{array}$ & $\begin{array}{l}\text { Chapeuzinho } \\
\text { Vermelho } \\
\text { João e Maria }\end{array}$ & $\begin{array}{l}\text { Avião } \\
\text { Onibus } \\
\text { Trem }\end{array}$ \\
\hline Menos típicos & $\begin{array}{l}\text { Amor-perfeito } \\
\text { Orquídea } \\
\text { Girassol }\end{array}$ & $\begin{array}{l}\text { Robin Hood } \\
\text { Bela Adormecida } \\
\text { Gato de Botas }\end{array}$ & $\begin{array}{l}\text { Escada rolante } \\
\text { Elevador } \\
\text { Bonde }\end{array}$ \\
\hline Menos típicos ainda & $\begin{array}{l}\text { Violeta persa } \\
\text { Azaléia } \\
\text { Yucca }\end{array}$ & $\begin{array}{l}\text { Rainha da Neve } \\
\text { Pequena Sereia }\end{array}$ & $\begin{array}{l}\text { Submarino } \\
\text { Teleférico } \\
\text { Cadeira de rodas } \\
\text { automática }\end{array}$ \\
\hline Pouco típícos & $\begin{array}{l}\text { Rafflesia } \\
\text { Flores de gramíneas }\end{array}$ & $\begin{array}{l}\text { O mágico de Oz } \\
\text { O Gato de Botas }\end{array}$ & $\begin{array}{l}\text { Dirigível } \\
\text { Balão } \\
\text { Esteira } \\
\text { transportadora }\end{array}$ \\
\hline
\end{tabular}

Figura 4 - Estrutura graduada de três categorias ${ }^{15}$.

Note que o arranjo dos conceitos nas categorias varia com a cultura; a figura representa uma perspectiva americana (Fonte: IYER, 1995).

Para uma melhor compreensão da noção de estrutura graduada de categorias, Iyer (1995) descreve as suas características pelos seguintes aspectos:

15 Alguns membros descritos na categoria 'Contos de Fada' do original em Inglês não possuem versão para o Português, razão pela qual não constam nesta versão traduzida. 
1. que as categorias de estrutura graduada não possuem qualquer propriedade inerente ou "natural", como as categorias clássicas. Categorias taxonômicas podem ser observadas linearmente; peixes são igualmente diferentes de pássaros. Mas outros tipos de categorias não possuem representação clara; caso contrário, o que poderia definir as propriedades de "rosa"?

2. que todos os membros de categorias não são iguais, e a estrutura categorial é marcada por uma graduação ou tipicalidade, na qual alguns membros são melhores que outros.

3. que a estrutura categorial é assimétrica.

4. que isso leva a uma abordagem ecológica e comportamental de categorização de como pessoas classificam objetos dentro da categoria de acordo com a sua caracterização.

5. que tais categorias são essencialmente instáveis, constantemente redefinidas de acordo com a abordagem que delas fazemos em diferentes contextos, e levando em conta a sua utilização. Mais freqüentemente, agrupamos objetos de acordo com nossos propósitos imediatos. Por exemplo, uma categoria cujas propriedades são documentos, roupas, escova de dentes, lâmina de barbear e passaporte parece bastante inexpressiva. Elas [propriedades] não compartilham nenhuma estrutura similar, servem a diferentes propósitos e são mantidas em diferentes categorias. Certamente, não servem às exigências do paradigma clássico de possuir necessária e suficentemente as mesmas propriedades. Entretanto, quando elas são colocadas juntas como itens de uma viagem de negócios, a categoria é facilmente identificada. Nenhum desses objetos pertencem exclusivamente a essa categoria, e a própria categoria pode tornar-se inútil se a viagem não existir e pararmos de pensar nelas [propriedades] num contexto particular. A categorização se transforma, então, não numa estrutura para definir o universo, mas sim num processo para conceder subsídios para o pensar, momentaneamente úteis para agrupar por associação. Essa abordagem é especialmente relevante para usuários na busca de informação, e o modo como categorizam conceitos no momento, para expressar suas necessidades informacionais imediatas. Por exemplo, quando um usuário busca pela categoria chamada classificação, a necessidade imediata pode ser para informação em esquemas de classificação bibliográfica, tais como a LC e a CDD. O usuário está buscando somente as ferramentas utilizadas para organizar informação. Outro usuário pode estar buscando matérias em psicologia, ciência cognitiva, aprendizagem da linguagem ou, inteligência artifical relacionada à informação em classificação. 
A informação na categoria "classificação" para esses usuários poderia ser significativamente diferente; o que constitui que a categoria "típica" é também um assunto de perspectiva, e o designer de informação que maneja ferramentos e sistemas de busca de informação deve estar atento a essa questão. Halsey (Halsey, 1989, p.89) observa que "o desafio mais excitante na teoria da classificação será aprender como relacionar a estrutura conceitual de textos, gráficos e dados, e a estrutura cognitiva de usuários e da alteração de suas percepções através do tempo". Isso poderá adquirir uma interface do usuário que relacione as várias estruturas de conhecimento dos usuários com uma estrutura universal classificatória nas ferramentas de classificação e indexação usadas para organizar sistemas de informação (IYER, 1995, p.43-45).

A perspectiva de categorização apresentada por Iyer sugere que, assim como indicam as contribuições sobre o tema dadas pelo II Wittgenstein, e pela semântica cognitiva, por Rosch, deverão ser observadas mais demoradamente pela CI contemporânea. 
"Bem! Já vi muitas vezes um gato sem sorriso, pensou Alice; mas um sorriso sem gato? É a coisa mais curiosa que já vi na minha vida" (Carroll, L. Alice no país das Maravilhas).

O objetivo desse trabalho foi o de compreender o funcionamento da categorização e verificar como a noção foi explorada na elaboração de linguagens documentárias em diversos momentos. É sensato afirmar que a complexidade da questão, não permite, nos limites deste trabalho, uma avaliação conclusiva. Foi possível, porém, enumerar algumas referências para futuras pesquisas a partir da reunião de algumas reflexões sobre o tema.

As teorias filosóficas sucintamente repertoriadas, bem como as contribuições da semântica cognitiva de Lakoff e da sociologia de Mauss, mostram várias maneiras como o conceito de categoria e a atividade de categorização foram delineadas no tempo. A experiência, a partir de Kant, começa a ser integrada aos modos de categorização, idéia que é reiterada quando o homem, primeiro individualmente, e depois socialmente, passa a ser considerado nos processos de organização do mundo. A questão das relações do homem com o homem e com o seu meio têm conseqüências definitivas nas formas de categorização. 
Ao final do trabalho, somos tentados a encontrar um ponto comum entre os vários modos de abordar a questão da categorização, como meio de encaminhar uma proposta para um avanço nas discussões. Nesse sentido, quatro principais direções são apontadas.

A primeira direção consiste em constatar que existe uma relativa flexibilização, ao longo do tempo, na noção de categorização. Desde Aristóteles, muito embora se considerasse as categorias como descritivas - ou sem enlace - os termos com enlace anunciam a possibilidade de sua aplicação concreta. A base sócio-cultural da categorização é uma das formas de integrar as diferentes experiências.

Sob esse prisma, é importante recuperar (e comungar) com uma visão crítica dada por García Gutiérrez (2006). Discutindo a análise do conhecimento e sua atual organização, questão que considera vinculada convencionalmente ao conhecimento ordenado e elitista, o autor afirma que grande parte do conhecimento socialmente produzido é ignorado, já que na perspectiva epistemológica tradicional "prevalecem as hierarquias férreas, sujeitas a matrizes cognitivas e culturais ancestrais" (GARCÍA GUTIÉRREZ, 2006, p.106). A questão a ser enfrentada seria verificar "quem teria legitimidade para estabelecer distinções entre os conhecimentos ou levantar fronteiras entre eles" (Ibid., p.104). Para o autor o problema tem de ser visto sob duas dimensões culturais diferentes: a do submundo, no qual subsiste a percepção profunda e diversa, composta de uma população sem-terra e de habitantes de 
favelas; e a de um mundo idealizado, "minoritário, imaginário e unificador, inventado" e "vivido pelas elites financeiras, petroleiras e latifundiárias" (Ibid., p.105). Mais além, acusa a Epistemologia de estrutura dominadora e exclusivista, enquanto criatura de sociedades por nós acalentadas que "foram e são tão invasoras como invasivas" (Ibid., id.). Nelas impera a marca da dominação. Sob seu ponto de vista, "todas as instâncias têm direito à razão e ao direito de transmiti-la em igualdade de condições" (Ibid., p.104), o que o leva a interrogar sobre a consistência da lógica que considera "uma estrutura culturalmente determinada" (Ibid., p.106). O autor se refere à lógica ocidental lembrando a dos idosos de uma etnia da Papua-Nova Guiné que, para morrer, escolhem ser enterrados vivos sob os detritos de seu gado a se internarem num hospital australiano, o que considerariam indigno e humilhante. Na verdade, o autor acredita que os contextos culturais influenciam as lógicas, que no seu entender, são crenças. Em seu vagar incansável à procura de uma resposta alentadora, propõe uma outra configuração disciplinar que denomina como Epistemografia, que seria capaz de atender a todas as nuances sociais e suas formas de expressão.

A segunda direção, conseqüência da primeira, ressalta a categorização como algo cuja validade é provisória, circunstancial, e acima de tudo, possui uma propriedade interativa e condição para o exercício da interatividade e abertura com seus públicos. A transformação das sociedades e o reconhecimento dos vários modos de viver no mundo 
solicitam uma tal compreensão, cujos reflexos na elaboração de linguagens documentárias e organização de informação são inevitáveis.

A terceira direção é pragmática para a Ciência da Informação, ressaltando os processos de categorização e sua ligação com o fazer que correlaciona sistemas de informações e públicos visados. Fora do âmbito da comunicação de massas, a observação dos públicos é condição necessária para tornar a informação instrumento de conhecimento efetivo. A observar, o fato de que a inserção da atividade documentária nos diferentes espaços de socialização do conhecimento solicita reconhecer os diferentes espaços sócio-culturais onde a ação se realiza. Pode-se notar, pela progressão identificada nos modos de categorização, que ela se relaciona à própria desconstrução da noção formal de Ciência. Como afirma Coutinho,

Em uma categorização clássica gostaríamos de captar da coisa aquilo que nela é essencial (...) [A]o lidar com a Ciência, estamos tratando com uma categoria mal comportada, que não possui uma essência definidora. A atividade científica e a busca pelo conhecimento são por demais complexas para serem definidas em sua essência. Levis Carroll, em Alice no país das maravilhas, nos apresenta o Gato de Chesshire, que era capaz de desaparecer, embora permanecesse o sorriso. Essa figura incômoda pode ser encarada, então, como a fórmula de acidentes sem uma essência. Temos o acidente risonho, mas não temos uma essência que ri (COUTINHO, F.A., 2002, p.37) ${ }^{16}$.

A quarta direção resulta da análise, ainda que sumária, das contribuições de autores clássicos da Biblioteconomia, geralmente no âmbito dos

${ }^{16}$ Do autor, emprestamos a epígrafe destas Considerações Finais. 
estudos de Teoria da Classificação, como também dos contemporâneos, que mostra que a forma de discutir categorias nem sempre é enfrentada de modo a propor o amadurecimento teórico e metodológico necessário à elaboração de linguagens documentárias. A raiz do problema talvez esteja na ausência de distinção entre classificação e categorização quando se discutem os instrumentos de organização. Trata-se de dois princípios diferentes: o foco na ação de classificar e o foco na ação de categorizar.

As noções de categoria e classe - e por conseqüência, categorização e classificação - não são excludentes, mas complementares. Uma classe é organizada a partir de propriedades, mas uma vez definida a classe, a operação a ser realizada a partir dela é a de encaixe, não de análise das propriedades. Trata-se exclusivamente de utilizar procedimentos analíticodedutivos.

A dificuldade talvez se deva ao fato de que, com o decorrer do tempo, os sistemas de classificação sofrem modificações passando a operar simultaneamente com base no encaixe de classes e na análise das propriedades de um conceito. Uma comparação entre a CDD e a CDU, ambos sistemas enciclopédicos, permite mostrar que a primeira se aproxima de uma taxonomia, sendo que sua utilização exige que se opere com classes, de forma dedutiva, sendo raros os procedimentos de síntese de características previstos; a segunda, opera tanto com classes, como a partir do reconhecimento de propriedades. Dito de outro modo, a CDU não se esgota no encaixe de classes, abrindo também a possibilidade de 
observar o conteúdo dos documentos - quando se aproxima do tesauro. Este aspecto permite caracterizar a CDU como um sistema misto, o que foi possível particularmente pela introdução de operadores de relação para contemplar 'aspectos' que não são passíveis de serem tratados no âmbito exclusivo de uma classe. A incorporação desses procedimentos na CDD é tímida. Por isso mesmo se admite que a CDU, diferentemente da CDD, é um sistema analítico-sintético.

O mesmo raciocínio se aplica à CC que, embora proposta como uma classificação enciclopédica, tem subjacente a possibilidade da análise particularizada de características dos conceitos (a partir da combinação dos 'isolados', na terminologia de Ranganathan, por meio das relações de fase anteriormente citadas). Com Otlet e La Fontaine, como com Ranganathan, se inicia uma nova fase, qual seja, a passagem da Biblioteconomia (classificação) para a Documentação (indexação), que inaugura a utilização de procedimentos de natureza analítico-sintética cuja continuidade marca as classificações especializadas. Com os tesauros, o privilégio das propriedades sobre as classes é mais enfatizado.

Um paralelo entre a classificação de Lineu e a de Buffon ajuda a compreender o fato. Como salienta Lara Filho (2006), Lineu propõe descrever a História Natural sob duas grandes categorias: Reino Animal, Reino Vegetal. A classificação universal do reino vegetal, por exemplo, se baseia na descrição das plantas relacionando suas classes, gêneros e espécies adotando como referência os órgãos de reprodução, mas 
desprezando seus outros elementos (folhas, caule, raízes). Buffon, ao contrário, não aceita a proposta de Lineu, observando que as divisões sucessivas em classes, gêneros e espécies não são isentas de arbitrariedade. Observa Buffon que a natureza não é estática, mas caminha por "gradações desconhecidas", o que impediria utilizar tais divisões, já que muitas vezes se passa de um gênero a outro por nuances imperceptíveis. A utilização desse sistema seria perturbada pela presença de espécies intermediárias e meio-objetos. Lineu era fixista, supondo a natureza como um todo coeso e estável, sem variações das espécies; Buffon, evolucionista, propondo que uma classificação deve observar as relações do homem com a natureza, observando sua mobilidade e comportamentos. Para Foucault, segundo Lara Filho (LARA FILHO, 2006), a divergência entre Lineu e Buffon é uma diferença entre duas formas de resolver o mesmo problema: utilizando um sistema (Lineu) ou um método (Buffon). O sistema é um conjunto limitado de traços a partir de uma escolha que dará lugar a identidades e diferenças; o método, ao contrário, não parte da totalidade para o recorte dos elementos, antes os deduz progressivamente começando pela descrição exaustiva de um primeiro exemplar, a partir do qual serão descritos outros exemplares pelo acréscimo de suas diferenças.

O paralelo permite mostrar que o método que parte das propriedades é mais eficiente para dar conta de ocorrências futuras, nem sempre previsíveis, ao contrário das classes, fixadas de início. 
Tais diferenças também podem ser remetidas à alteração na forma de ver as categorias. As categorias aristotélicas são de natureza descritiva e se referem aos tipos de enunciado que indicam os modos distintos de dizer, de descrever; as categorias kantianas são explicativas, como função do pensamento. Como vimos anteriormente, à diferença de Aristóteles, Kant considera que as categorias são 'conceitos puros de entendimento'. Não são gêneros de coisas, não descrevem a realidade, mas tornam possível explicá-la. Ao propor a dedução transcendental, Kant coloca o sujeito no centro e afirma que as categorias seriam a explicação do modo como conceitos a priori se referem a objetos. Distingue a dedução transcendental da dedução empírica, que indica a maneira como o conceito foi adquirido por meio da experiência e reflexão. As categorias, então, são entendidas do ponto de vista transcendental, como 'condições de possibilidade'. Tal alteração se reflete, certamente, na forma de organização da informação, o que pode explicar a relativização das formas de propor os arranjos organizacionais. Mas esse problema tem de ser observado de modo mais conseqüente para construir conhecimento no campo da Ciência da Informação.

Das quatro direções, ou antes aspectos acima levantados, pode-se afirmar que os três primeiros têm de ser refletidos pelos pesquisadores da área da Ciência da Informação sem o que não se pode afirmar uma quarta direção nítida, onde as facetas da categorização relacionadas à flexibilização, validade provisória e diversidade de públicos, sejam observadas de modo a dar conta da natureza da informação na contemporaneidade. Mais que 
isso, é preciso observar que a expressão da categorização se faz em linguagem, talvez a maior razão das dificuldades a serem enfrentadas. 
BARRETO, A.A. (1999). Os destinos da ciência da informação: entre o cristal e a chama. Inf. \& Soc.: Est., João Pessoa, v.9, n.2, p.371-382.

BAUMAN, Z. (1999). Modernidade e ambivalência. Rio de Janeiro:Jorge Zahar. 334p.

BLAIR, D.C. (2003). Information retrieval and the philosophy of language. Annual Review of Information Science and Technology (ARIST), v.37, p.3-50.

(2006). Wittgenstein, language and information: back to the rough ground! Dordrecht/The Netherlands: Springer.

CHAUÍ, M.S. (1995). Convite à filosofia. 6.ed. São Paulo: Ática. 440p.

CITELLI, A. (2000). Comunicação e educação: a linguagem em movimento. São Paulo: Ed. SENAC.

COUTINHO, F.A. (2002). Conhecimento. In: MARTINS, R.P. \& MARI, H., eds. Universos do conhecimento. Belo Horizonte: Faculdade de Letras da UFMG. Cap. 1, p.17-40.

CUENCA, M.J.; HILFERTY, J. (1999). Introducción a la lingüística cognitiva. Barcelona: Ed.Ariel. 251p.

DAHLBERG, I. (1972). Teoria da classificação, ontem e hoje. Disponível em: http://www.conexaorio.com/biti/dahlbergteoria/dahlberg teoria.htm. Acesso em: 10/07/2005. 
DAHLBERG, I. (1978). Ontical structures and universal classification. Bangalore: Sarada Ranganathan Endowment for Library Science. 64p.

- (1979). O futuro das linguagens de indexação. Disponível em: http://www.conexaorio.com/biti/dahlberg/index.htm. Acesso em: 07/06/2005.

ECO, U. (1998). Marco Polo e o unicórnio. In: . Kant e o ornitorrinco. Trad. de Ana Thereza B; Vieira. Rio de Janeiro; São Paulo; Record. p.55-56.

FERRATER MORA, J. (1971). Diccionario de filosofía. Buenos Aires: Ed. Sudamericana. $2 \mathrm{v}$.

FONSECA, E.N. (1976). Apogeu e declínio das classificações bibliográficas. Disponível em: http://www.conexaorio.com/biti/nery/index.htm . Acesso em: 06/06/2005.

GARCíA GUTIÉRREZ, A.; LUCAS FERNANDÉZ, R. (1987). Lenguages documentales e información de actualidad. In: Documentación automatizada em los medios informativos. Madrid: Paraninfo. p.67-90.

. (2006). Cientificamente favelados: uma visão crítica do conhecimento a partir da epistemografia. TransInformação, Campinas, v.18, n.12, p.103-112, maio/ago.

GROLIER, E. (1962). Étude sur les catégories générales applicables aux classifications et codifications documentaires. Paris : UNESCO. 262p.

IYER, H. (1995). Classificatory structures: concepts, relations and representation. Frankfurt/Main: INDEKS Verlag. 232p. (Textbooks for Knowledge Organization, v.2).

JACOB, E.K. (2004). Classification and categorization: a difference that makes a difference. Library Trends, v.52, n.3 (541-571), Wntr.

LAKOFF, G. (1987). Women, fire and dangerous things: what categories reveal about the mind. Chicago: The University of Chicago Press. 614p.

LALANDE, A. (1992). Vocabulaire technique et critique de la philosophie. 2.ed. Paris: QUADRIGE/PUF. 2V. 
LARA, M.L.G. (s.d.) Conceito de organização. São Paulo: s.n. (Material para uso didático).

- (1999). Representação e linguagens documentárias: bases teóricometodológicas. São Paulo: ECA, 1999. (Tese de Doutorado).

. (2001). Dos sistemas de classificação bibliográfica às search engines, 1. São Paulo : APB, 2001. (Ensaios APB, n.90).

(2002). O processo de construção da informação documentária e o processo de conhecimento. Perspectivas em Ciência da Informação, Belo Horizonte, v.7, n.2, p.127-139. Disponível em: http://www.eci.ufmg.br/pcionline/viewarticle.php?id=155\&layout=abstract. $\quad$ Acesso em: 12/10/2006.

LARA FILHO, D. (2006). Museu: de espelho do mundo a espaço relacional. São Paulo: Escola de Comunicações e Artes (Dissertação de Mestrado).

LOPES, E. (1997). O nascimento da lingüística geral e do estruturalismo. In: A identidade e a diferença: raízes históricas das teorias estruturais da narrativa. São Paulo: EDUSP.

MARI, H. (2002). Categorização. In: MARTINS, R.P.; MARI, H., eds. Universos do conhecimento. Belo Horizonte: FALE-UFMG. p.67-89.

MARQUES, J.O.A. (s.d.). Pensar o sentido de uma proposição. Disponível em: http://www.cfh.ufsc.br/ wfil//imarques2.htm. Acesso em: 30/11/2006.

MAUSS, M. (2001). Ensaios de sociologia. São Paulo: Perspectiva. 493p.

MORENO, A. R. (2000). Wittgenstein: os labirintos da linguagem: ensaio introdutório. São Paulo: Ed. Unicamp. 128p.

PIEDADE, M.A.R. (1977). Introdução à teoria da classificação. Rio de Janeiro: Interciência. 185p.

SHERA, J. (1957). Padrão, estrutura e conceituação na classificação. Disponível em: http://www.conexaorio.com/biti/shera/\#ref1. Acesso em: 09/03/2005.

SMIT, J.; TÁLAMO, M.F.G.M., KOBASHI, N. (s.d.). Categorias. São Paulo: s.n. (Material para uso didático). 
TÁLAMO, M.F.G.M. (1997). Linguagem documentária. São Paulo: APB. 12p. (Ensaios APB, n.45).

VARGAS LLOSA, M.. (2006). Filosofia doméstica para tornar a vida mais compreensível e tolerável. O Estado de S.Paulo, São Paulo, Domingo, 11 Junho, Caderno 2, p.D8.

VICKERY, B.C. (1980). Classificação e indexação nas ciências. Rio de Janeiro: BNG / Brasilart União. 274p. 